\title{
Various marginal marine environments in the Central Paratethys: Late Badenian and Sarmatian (middle Miocene) marine and non-marine microfossils from Pécs-Danitzpuszta, southern Hungary
}

\author{
Szuromi-Korecz, Andrea ${ }^{1}$, Magyar, Imre ${ }^{2,3}$, SzTANó, Orsolya $^{4}$, Csoma, Vivien ${ }^{5}$, BotKa, Dániel ${ }^{1,5}$, \\ SeBE, Krisztina ${ }^{6}$, Tóth, Emőke ${ }^{5}$
}

'Laboratories MOL, MOL Hungarian Oil and Gas Plc., Budapest; kaszuroka@ gmail.com, botkadani@ gmail.com, ORCID: 0000-0002-6627-4640 ${ }^{2}$ MOL Hungarian Oil and Gas Plc., 1117 Budapest, Október huszonharmadika u. 18, Hungary; immagyar@mol.hu, ORCID: 0000-0002-9236-0040 ${ }^{3}$ MTA-MTM-ELTE Research Group for Paleontology, Budapest, Hungary

${ }^{4}$ ELTE Eötvös Loránd University, 1117 Budapest, Pázmány Péter sétány 1/c; orsolya.sztano@ ttk.elte.hu, ORCID: 0000-0003-0786-3653 5Department of Palaeontology, ELTE, Budapest; csoma.vivien7@ gmail.com, ORCID: 0000-0002-2593-5537; tothemoke.pal@ gmail.com; ORCID: 0000-0002-1733-7828 ${ }^{6}$ University of Pécs, Department of Geology and Meteorology, 7624 Pécs, Ifjúság útja 6, Hungary, sebe@ @amma.ttk.pte.hu, ORCID: 0000-0002-4647-2199

\section{Késô badeni és szarmata (középsố miocén) mikrofossziliák Pécs-Danitzpusztáról}

Összefoglalás

A Középsô-Paratethys középsô miocén foraminifera és kagylósrák együttesei általában stabil normál tengeri viszonyokat tükröznek a badeniben, míg térben és időben változatosabb, mozaikos környezeteket a szarmatában. A pécs-danitzpusztai homokbányában kiásott kutatóárokban 17 méter vastagságban tárult fel a tektonikusan kibillentett középső miocén rétegsor, amely jelentős környezeti változásokról tanúskodik a késő badeni és a pannóniai között. A rétegsor alján normál tengeri, sekélyvízi, meleg, jól szellőzött, aránylag nagy energiájú, mikrobaszónyeges aljzatú környezetre utalnak a mészkő-, márgarétegek mikrofosszíliái. A foraminiferák alapján ezek a rétegek a késő badeniben (13,82 és 12,65 millió év között) rakódtak le. A szelvény középső szakaszán a tengeri rétegeket mikrofosszília-mentes, gravitációsan áthalmozott durva homok-breccsa, aleurolit váltakozásából álló sorozat követi, amelyben valószínúleg szárazföldi kitettségre utaló gyökérbekérgezéseket is találtunk. A következô tengerelöntés éles kőzettani váltás mellett a szelvény felsố részéből kinyert mikrofosszíliák alapján a késô szarmatában történt, kb. 12 és 11,6 millió év között. Ezek a rétegek a felsô szarmata Porosononion granosum zónát (foraminiferák) és Aurila notata zónát (kagylósrákok) képviselik. Az együttesek kizárólag tágtűrésű fajokból állnak, és változó só-, oxigén- és tápanyagtartalmú, növényzettel rendelkező, brakkvízi tengeri környezetet jeleznek. Az 5 m vastag felső szarmata egységben néhány rétegből, amelyek együttesen egy métert képviselnek, édesvízi vagy legfeljebb oligohalin kagylósrákfauna és kivételesen tág sótûrésû foraminiferák kerültek elő. Az együttesek megváltozását nem kíséri jelentős litológiai váltás, nincs jele megnövekedett szárazföldi eredetú behordásnak, amely egy közeli folyótorkolatot jelezne. Sem a késő szarmata geomorfológiai viszonyok, sem a kőzetminóség nem utal a tengertől részben elzárt környezet (lagúna, parti mocsár) kialakulására. A helyi viszonyokon túlmutató tényezők (pl. az éghajlat változása) nagyobb területen is megfigyelhető lenne, ilyen adatokkal azonban nem rendelkezünk. A tágtúrésú foraminiferák és édesvízi-oligohalin kagylósrákok megjelenése mindenesetre helyben vagy a közelben élő közösségre utal, és így a helyi alacsony (5-10\%o) sótartalmat jelzi. Ilyen közösséget más szarmata szelvényből a KözépsőParatethys területén eddig nem ismertünk. A szelvény tetején a foraminiferák hirtelen eltúnése és ezzel egy időben a kagylósrákfauna teljes kicserélődése a szarmata és pannóniai emeletek határát jelöli ki (11,6 millió év).

Kulcsszavak: Középsó-Paratethys, Mecsek, foraminifera, kagylósrák, taxonómia, biosztratigráfia, paleoökológia

Abstract

The middle Miocene foraminifera and ostracod record of the Central Paratethys usually reflects stable normal marine depositional environments for the Badenian and more patchy, less stable restricted marine environments for the Sarmatian. A 17 m thick outcrop at Pécs-Danitzpuszta, Mecsek Mts, SW Hungary exposed an upper Badenian to Pannonian succession where foraminifers and ostracods document significant environmental changes. The basal layers of the section contain micro- and macrofossils indicating normal marine, shallow, warm, well-oxygenated habitat with relatively high-energy conditions and algal vegetation on the bottom, and represent the upper Badenian (13.82 to 12.65 Ma). The marine deposits are followed by coarse sandstone, breccia and siltstone layers barren of microfossils but containing rhizoliths. The sediments were probably subaerially exposed for some time. The following marine inundation, marked by the appearance of clays and limestones as well as fossils, was dated to the late Sarmatian (ca. 12 to $11.6 \mathrm{Ma}$ ) on the basis of the restricted marine microfossil assemblages from the upper part of the succession (Porosononion granosum Zone, Aurila notata Zone). This community is characterized by exclusively eurytopic forms indicating an unstable and vegetated marginal marine environment with fluctuations in salinity, as well as oxygen and food availability. Within the $5 \mathrm{~m}$ thick upper Sarmatian marine interval, a unique fresh- to oligohaline fauna characterizes a few layers in less than $1 \mathrm{~m}$ thickness. This fauna consists of highly euryhaline foraminifera and freshwater to oligohaline ostracod assemblages, indicating a 
temporary salinity reduction to $5-10 \%$. No similar freshwater fauna has been reported from the Sarmatian of the Central Partethys so far. The eventual disappearance of the foraminifera from the paleontological record coupled with a complete turnover in the ostracod fauna indicates the transition from the marginal marine Sarmatian Sea to the brackish Lake Pannon, marking the Sarmatian/Pannonian boundary (11.6 Ma).

Keywords: Central Paratethys, Mecsek Mts, Foraminifera, Ostracoda, taxonomy, biostratigraphy, paleoecology

\section{Introduction}

The distribution of marine microorganisms in an epicontinental sea is driven by the local and regional changes of environmental conditions such as salinity, water temperature, oxygen-level, food availability, substrates, and water depth. These environmental conditions and the evolution of the microfauna were controlled by the openings and closures of the seaways towards the adjacent seas and the world ocean in the Paratethys, an epicontinental sea of central and eastern Europe during the Oligocene and Miocene (RöGL 1998, PoPOV et al. 2004). The connection toward the Mediterranean Sea was terminated due to the uplift of the Dinarides at the Badenian/Sarmatian boundary, triggering an endemic evolution of the marine faunas in the Paratethys (e.g., Palcu et al. 2015). The seaway towards the Indopacific was closed in the late Sarmatian, eliminating the last Indo-Pacific planktonic elements that were detected in the Transylvanian Basin (FILIPESCU \& SILYE 2008). All of these changes might have influenced the biota at the study area in SW Hungary.

The present study focuses on the taxonomy and paleoecological and biostratigraphical interpretation of foraminifer and ostracod communities from a middle Miocene succession exposed in an exploratory trench in the Pécs-Danitzpuszta sand pit, Mecsek Mts, SW Hungary. Earlier studies of middle Miocene foraminifera in Hungary (BÁLDI 1999, 2006; BÁLDI et al. 2002; BÁLDI 2006; GÖRÖG 1992; KORECZLAKY 1964, 1965, 1968, 1973, 1982; KORECZ-LAKY \& NAGYGELLAI 1985; TóTH \& GöRÖG 2008) showed the wide distribution of the normal marine Badenian and restricted marine (brackish and hypersaline) Sarmatian faunas, which are well-known in the entire Central Paratethys. The study of Sarmatian ostracods resulted in a biostratigraphic system for the entire Pannonian Basin (То́тн 2004, 2008), whereas Badenian ostracods from Hungary have not been studied yet. By investigating the Pécs-Danitzpuszta micropaleontological record, we give the first documentation of Badenian ostracods from Hungary and also describe a so far unknown upper Sarmatian non-marine ostracod assemblage.

\section{Geological setting}

The Pécs-Danitzpuszta sand pit lies in the eastern outskirts of Pécs, at the foot of the Mecsek Mts (Figure 1). The region north of the sand pit is built up of Mesozoic rocks, mostly Lower Jurassic marls and sandstones, overlain by a succession of lower to middle Miocene terrestrial clastics and middle Miocene marine clastics and carbonates (SEBE et al. 2015, 2019; SEBE et al. 2021). These are capped by upper
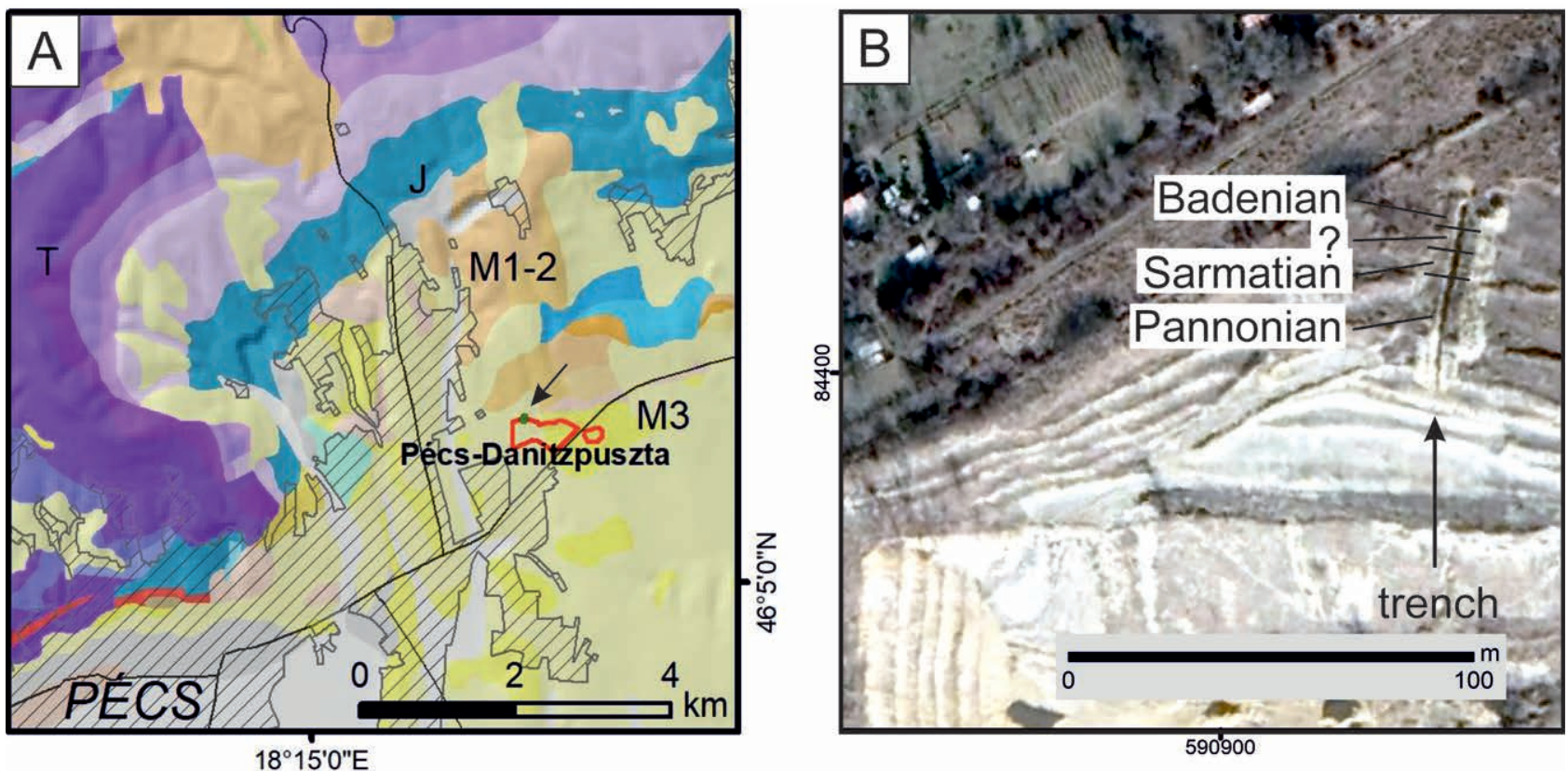

Figure 1. Location of the Pécs-Danitzpuszta sand pit (A) and the exploratory trench (B)

1. ábra. A pécs-danitzpusztai homokbánya (A) és a kutatóárok (B) elhelyezkedése 
Miocene (Pannonian) marls and sands, exposed in many outcrops around the Mecsek. The boundary between Sarmatian and Pannonian deposits is continuous in (sub)basin centres, while they are separated by an unconformity with increasing hiatus towards the margins. Similar, but several $\mathrm{km}$ thick Neogene successions were reported from the Drava Basin to the south and southwest (SAFTić et al. 2003; SEBE et al. 2020) reflecting the opening and evolution of the Pannonian Basin, flooding by the Paratethys sea and later by the brackish Lake Pannon.

\section{Material and methods}

\section{Studied section of Pécs-Danitzpuszta sand pit}

The sand pit exposes strongly tilted upper Miocene (Pannonian) calcareous marls and sands. In 2018, an exploratory trench was excavated in the northwestern part of the sand pit across the tilted beds that underlie the exposed Pannonian marl (Figure 1). The trench revealed the lowermost part of the Pannonian succession and the underlying Sarmatian and Badenian deposits. Due to tectonic deformation, most of the exposed succession is overturned, and the stratigraphically lowest (oldest) layers are located in the north (SEBE 2021). Overturned beds become steeper towards the south (upsection) and they are almost vertical close to the southern end of the trench. The oldest part of the studied section is represented by yellowish white calcareous marl (Layer D72) in the northern end of the trench (Figures 2, 3). It contains a typical Badenian mollusk fauna and belongs to the Lajta Formation (SEBE et al. 2021, DULAI et al. 2021). D71 also shows features typical of the Lajta Limestones: it is a sandy limestone with corallinacean algae, echinoids, abundant molluscs, and sporadic fish remains (Dulai et al. 2021, SEBE et al. 2021, SzABó et al. 2021). The following beds (D70 to D57) did not provide stratigraphically valuable fossils; thus, their age is uncertain (Figure 2). These are unconformably overlain by a ca. $5 \mathrm{~m}$ thick unit of alternating thin clay, marl and limestone beds (layers D56-D36), identified as the Sarmatian Kozárd Formation based on its fossil content and lithology (SEBE et al. 2021).

\section{Micropaleontological samples and methods}

Fifteen middle Miocene samples from the trench were studied for their foraminiferal and ostracod content (Figures 2 , 3). The samples derived from soft sediments (about $200 \mathrm{~g}$ of air-dried clayey, sandy and marly sediments) were processed with hydrogen-peroxide (10\%). Hard limestones and calcareous marls were examined in thin sections, or the samples were treated by acetolysis following a protocol originally worked out by LETHIERS \& CRASQUIN-SOLEAU (1988) to extract the isolated carbonate skeletal microfauna. The applied extraction methods and the frequency of the extracted fossil groups from the studied layers are summarized in Figure 4.
Thirteen samples yielded interpretable microfossil content; D57 and D69 were free of microfossils (Appendix). The microfossils were determinated using a Zeiss SteREO Discovery.V12 modular binocular stereo microscope in the Laboratory of MOL Plc., Budapest. Thin sections were prepared in the Laboratory of MOL Plc., Budapest and they were investigated with a Zeiss Axio Imager.A1 polarizing microscope. Microscopic images were taken by a Zeiss AxioCam MRc 5 camera, mounted on the Zeiss microscope, using the AxioVision $40 \times 64$ v.4.9.1.0 software. The SEM images were taken at the Botanical Department of the Hungarian Natural History Museum in Budapest.

\section{Results}

Relatively diverse and well-preserved benthic foraminiferal and ostracod assemblages were found in the studied middle Miocene beds. Altogether, 30 foraminifer and 32 ostracod taxa were identified (see Appendix and Digital an$n e x)$. The foraminifera specimens are moderately to wellpreserved, except for layers D70 and D71, where they were probably affected by transport of the tests and/or diagenetic processes. The ostracod specimens are disarticulated valves in most cases; however, a few carapaces also occur. The ostracod material is characterized by both adult and juvenile forms.

The oldest layer (D72) yielded the most diverse and abundant microfossil assemblage. Twenty-one foraminifera and 11 ostracod taxa were identified (Figure 2, Plate I). The foraminiferal assemblage was dominated by eurytopic taxa of keeled elphidiids (Elphidium aculeatum, E. crispum, and E. macellum) and miliolids (Borelis sp., Cycloforina contorta, Affinetrina ucrainica, Miliolinella selene, and Quinqueloculina hauerina). The ostracod fauna is characterized by the dominance of marine neritic taxa, such as Aurila cicatricosa, Callistocythere canaliculata, and Phlyctenophora arcuata. Urocythereis kostelensis, Loxoconcha punctatella, Loxocorniculina hastata, Xestoleberis dispar, and Polycope sp. also occur in low abundance. Besides foraminifers and ostracods, sample D72 also yielded significant amounts of echinoderm skeletal and spike fragments.

The microfossil assemblages of layers D70 and D71 were similar to, but significantly poorer than, that of D72. Poor preservation of the carbonate skeletons allowed only genus level determination in most cases (Xestoleberis sp., Callistocythere sp., Polycope sp., and Elphidium sp.). Echinoderm fragments were also more sporadic than in sample D72. The microfossils of layer D70 are probably reworked based on the scarcity and poor preservation of the specimens, although a diagenetic effect cannot be excluded either.

The soft sediments of layers D54 to D41 yielded a less diverse (5-10 taxa), well-preserved foraminifer and ostracoda fauna (Figure 2, Plates II-III). Among the foraminifera, exclusively eurytopic forms (taxa with wide environmental tolerance) were present. Keeled elphidiids with an acute periphery, sometimes equipped with spines, were the most common (e.g., Elphidium aculeatum, E. macellum, E. obtu- 


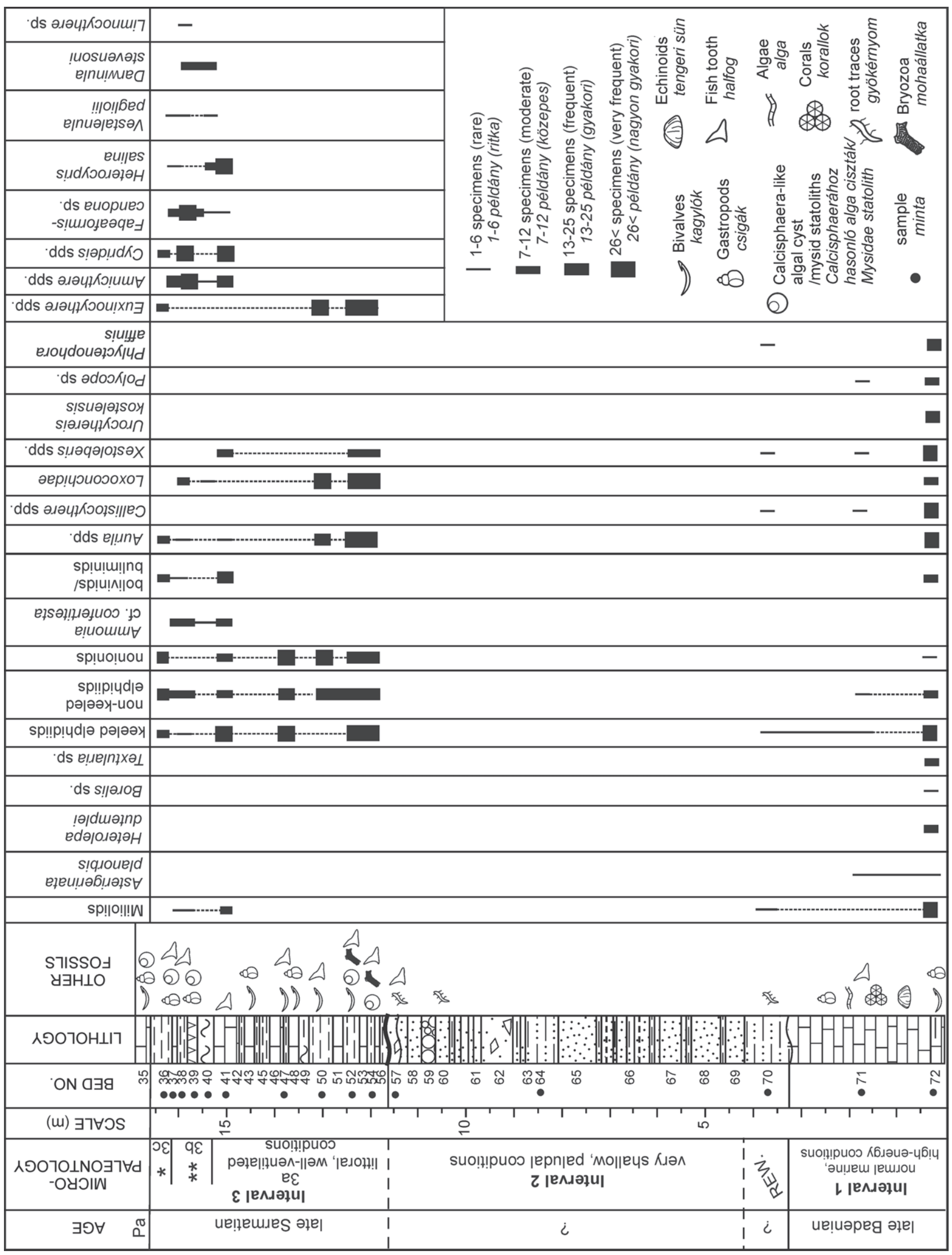




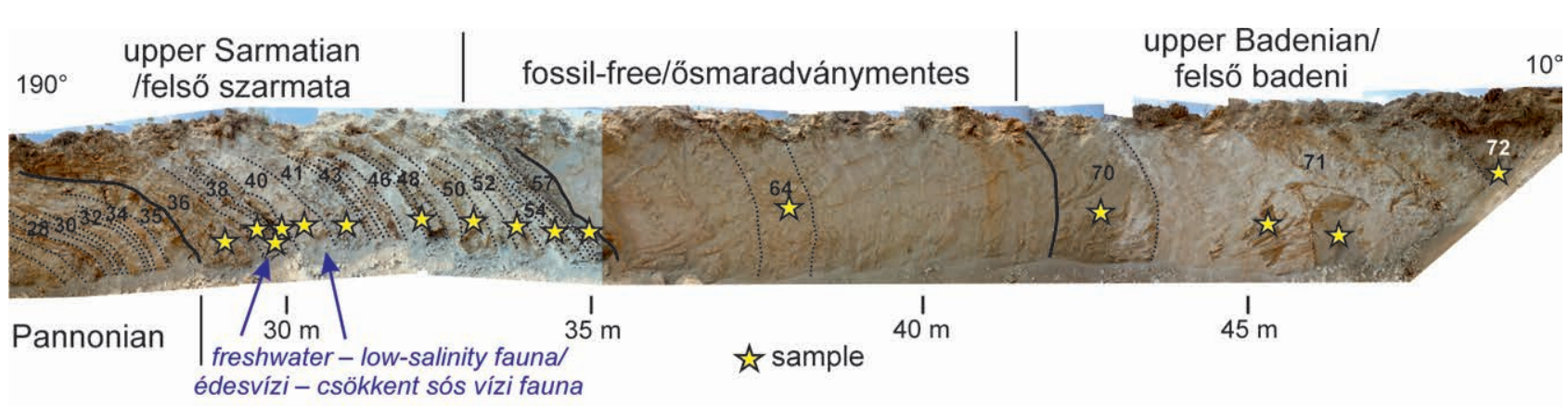

Figure 3. The northern part of the exploratory trench exposes overturned middle Miocene (D72 to D36) and stratigraphically overlying Pannonian (D35 to D28) layers. Sampling locations are indicated by yellow stars

3. ábra. A kutatóárok északi része, mely az átbuktatott középső miocén (D72 - D26) és a pannóniai rétegeket (D35 - D28) tárja fel. A sárga csillag jelzi a mintavételi helyeket

sum, and E. crispum). Among the non-keeled elphidiids, where the periphery of the tests is rounded or bluntly angular, specimens of Porosononion granosum were abundant. The ostracod fauna was characterized by different species of the genera Aurila, Loxoconcha and Euxinocythere (e.g., Aurila notata, Loxoconcha kochi, L. porosa, and Euxinocythere [Euxinocythere] praebosqueti). Specimens of Xestoleberis tumida are also present in the samples.

In layers D40 to D37, mainly specimens of the infaunal, non-keeled elphidiid $P$. granosum and Ammonia sp. were found (Figure 2). Beside the sporadic occurrence of marginal marine ostracods (e.g., Loxoconcha porosa and Aurila sp.), non-marine, freshwater to oligohaline ostracods, like Fabaeformiscandona sp., Heterocypris salina, Darwinula stevensoni, and Vestalenula pagliolii are present in the recovered assemblages.

Layer D36 is characterized by the dominance of eurytopic non-keeled elphidiids and nonionids and the representatives of leptocytherid Euxinocythere (E. [E.] praebosqueti and E. [E.] naca) (Plate II).

\section{Discussion}

\section{Biostratigraphy}

Benthic foraminifera are instrumental in the biostratigraphy of the middle Miocene sediments of the Central Paratethys, because the best index fossils, such as planktonic foraminifers and nannoplankton, are commonly missing from the fossil record, especially in the coastal regions (Figure 5).

$\leftarrow$ Figure 2. Sedimentary log of the middle Miocene part of the Pécs-Danitzpuszta succession, with sample locations, micropaleontological intervals and subintervals based on the stratigraphic distribution and ecological needs of the studied microfossil assemblages and the distribution of the paleoecologically important foraminifer and ostracod taxa and morphogroups in the samples Abbreviation: $\mathrm{Pa}=$ Pannonian

$\leftarrow$ 2.ábra. A pécs-danitzpusztai homokbányában kiásott kutatóárok középsö miocén szakaszának szelvénye a vizsgált minták feltüntetésével, a mikrofauna biosztratigráfiai és paleoökológiai értékelése alapján elkülönitett intervallumokkal, valamint a környezetjelzés szempontjából fontos foraminifera és ostracoda taxonok, illetve morfocsoportok megoszlásával

Rövidités: Pa= pannóniai
A commonly used threefold subdivision of the Badenian in the Pannonian, Vienna and Danube basins is partly based on the composition of benthic foraminifers reflecting distinct paleoenvironmental changes (PAPP et al. 1978). The lower Badenian is represented by the "Lagenidae Zone," the middle Badenian by the "Spiroplectammina Zone," and the upper Badenian by the "Bulimina/Bolivina Zone" (GRILL 1943, PAPP et al. 1978). Sarmatian sediments of the Pannonian, Vienna and Danube basins can be divided to four benthic foraminiferal zones: Anomalinoides dividens, Elphidium reginum, and Elphidium hauerinum Zones in the lower Sarmatian, and Porosononion granosum Zone in the upper Sarmatian (GRILl 1943, JIŘIČEK 1972, PAPP \& SENEŠ 1974). For the Sarmatian of the Pannonian Basin, Tóth (2009) proposed a two-fold ostracod zonation: Cytheridea hungaricaAurila mehesi Zone for the lower Sarmatian and Aurila notata Zone for the upper Sarmatian.

Layer D72 belongs to the upper Badenian based on the co-eval occurrence of Pyrgo subsphaerica (upper Badenian to recent) and Miliolinella selene (Badenian) among the foraminifera (ŁUCZKOwSKA 1974). Some ostracods in these layers, such as Urocythereis kostelensis and Phlyctenophora affinis, are restricted to the Badenian (GROSS \& PILLER 2006). Although the microfauna is dominated by eurytopic forms, normal marine taxa (e.g., Callistocythere canaliculata and Heterolepa dutemplei) also occur in these samples; they disappeared from the Central Paratethys at the end of the Badenian. Thus, the microfossil assemblages of layers D72 to D70 indicate late Badenian age, equivalent of the "Bulimina/Bolivina Zone" (13.82 to $12.65 \mathrm{Ma}$, according to HoHENEGGER et al. 2014 and RAFF et al. 2020), which correlates with the standard nannoplankton Zone NN6 (RöGL et al. 2008).

The presence of Aurila notata in layers D54 to D36 suggests correlation with the Aurila notata Zone (ca. 12 to 11.6 Ma). Several other taxa, such as Euxinocythere (E.) praebosqueti, E. (E.) naca, Loxoconcha kochi are also restricted to the upper Sarmatian in the Pannonian Basin (TóTH 2009). The foraminiferal assemblages are characterized by a great abundance of Porosononion granosum in almost all samples, indicating the Porosononion granosum Zone. This cor- 


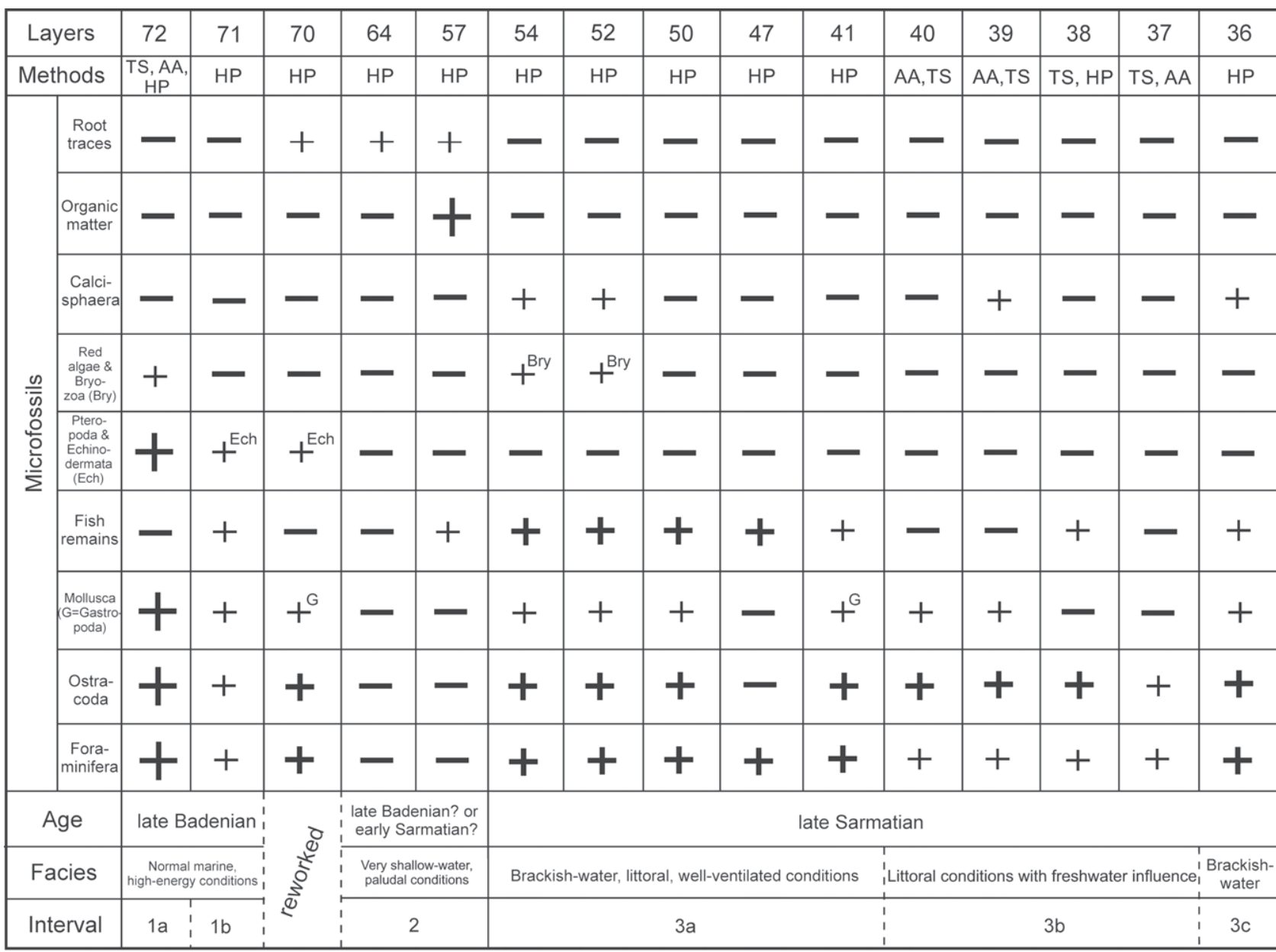

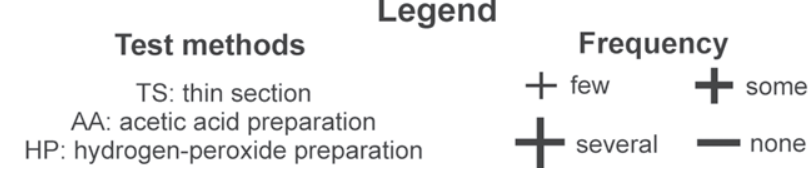

Figure 4. The extraction method of the studied layers and the frequency of the extracted fossil groups from the studied samples

4. ábra. Az egyes rétegek mintáinak mikropaleontológiai feltárási módszere, és a kinyert ősmaradványcsoportok gyakorisága a mintákban

relates with the younger part of the Aurila notata Zone (То́тн 2009). This biostratigraphic interpretation is in accordance with the nannoplankton zonation of the same layers (NN6 or younger, according to ĆORIĆ, 2021).

A sudden change in the microfossil assemblages can be observed between layers D36 and D35, indicating the Sarmatian/Pannonian boundary (11.6 Ma). Foraminifera are entirely missing from sample D35, and the ostracod faunas of the two samples are completely different, without any species in common. In D36, juvenile Aurila notata and Cyprideis sp. specimens, Loxocorniculum hastatum, Euxinocythere (Euxinocythere) praebosqueti, E. (E.) naca, and Amnicythere tenuis occur. In contrast, sample D35 is dominated by Candona and Herpetocyprella species. Calcisphaera-like large algal cysts and mysid statoliths (ballast stones of the shrimplike mysids; following the interpretation of VoICU 1981) are present in sample D35 in low abundance. These are characteristic fossils in strata near the S/P boundary at several locations in Hungary where it was not possible to precisely assign the boundary itself (e.g., KóVÁRY 1974, BARDÓCZ et al. 1987). Mysids are very common in unanimously Sarmatian layers of the Transylvanian and Dacian Basins (e.g., POPESCU 1995).

Despite the sharp microfaunal change, no major shift can be observed in the lithofacies of the sediment. The mollusc assemblage of sample D35 contains abundant "Sarmatian-type" small-sized cardiids (BоTKA et al. 2021). This fauna, affected by the Lilliput Effect (HARRIES \& KNORR 2009), is often related to environmental stress and has been published from the Sarmatian/Pannonian transition by several authors from different parts of the Pannonian Basin (e.g., Zsámbék Basin, Hungary, BoHN-HAVAS 1983; Lajoskomárom-1 well, Hungary, JÁMBOR et al. 1985; Medvednica Mts, Croatia, VRSALJKo 1999). Although the ostracod faunas of layers D36 and D35 are very different, and mollusks are missing from D36 while D35 shows the mass occurrence of tiny cardiid bivalves, it is not obvious if a short gap or continuous sedimentation occurred at the Sarmatian/Pannonian boundary. 


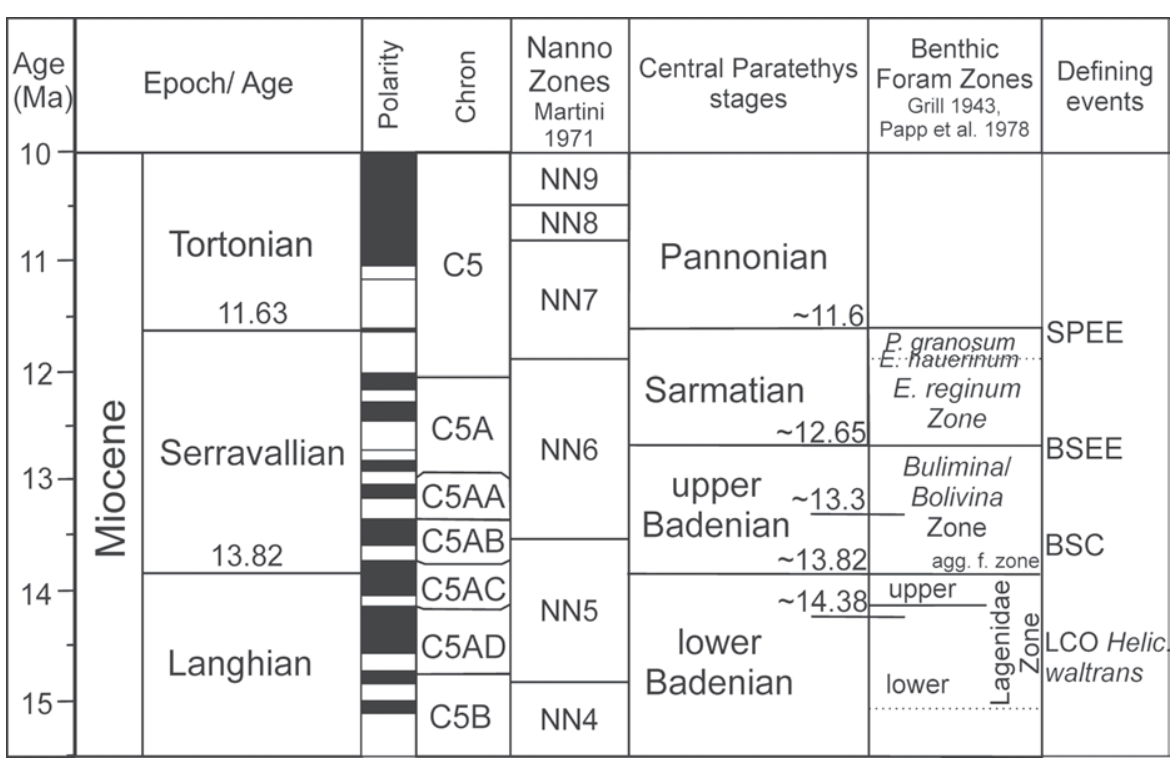

Fiure 5. Middle to upper Miocene geochronology, geomagnetic polarity chrons, biozonations of calcareous nannoplankton and benthic foraminifers correlated to regional chronostratigraphy of the Central Paratethys with defining events (modified after HoHENEGGER et al. 2014 and RAFFI et al. 2020).

Abbreviations: BSC= Badenian Salinity Crisis, SPEE $=$ Sarmatian-Pannonian Extinction Event, BSEE $=$ Badenian-Sarmatian Extinction Event (after Harzhauser \& Piller 2007)

5. ábra. Középső miocén rétegtani ábra radiometrikus koradatokkal, magnetosztratigráfiai és biosztratigráfiai (mészvázú nannoplankton, bentosz foraminifera) beosztással, illetve a Középsö-Paratethysben lejátszódott meghatározó események feltüntetésével (HOHENEGGER et al. 2014 és RAFFI et al. 2020 után módosítva).

Röviditések: $B S C=$ Badeni Sókrízis, SPEE = Szarmata/pannóniai kihalási esemény, BSEE= Badeni/szarmata kihalási esemény (HARZHAUSER \& PILLER 2007 után)

\section{Paleoecology}

Ecological requirements of the extant relatives of the studied middle Miocene taxa

Extant representatives of keeled elphidiids live in temperate to warm, shallow marine (at water depths up to $50 \mathrm{~m}$ ) environments (inner shelf) and hypersaline lagoons (MURRAY 1991, 2006). They are mostly epiphytic dwellers (live on plants) and prefer sandy sediment (LANGER 1993, MURRAY 2006). In the Mediterranean Sea, E. aculeatum and E. macellum live on arborescent algal vegetation (LANGER et al. 1998). They are chromatophore-bearing foraminifera and the "symbionts" may control the phototaxis and the depth distribution of the host organism. The chromatophores are pigment-containing cells that produce color. However, the nature of this symbiosis and the role of the chromatophores in phototaxis - the ability of organisms to move directionally in response to a light source - are poorly known. E. macellum is a common member of foraminiferal assemblages in the Black Sea living in the shallow sublittoral zone and coastal pools (down to $20 \mathrm{~m}$ depth) (TeMELKov 2008). Miliolinella and Quinqueloculina are epiphytic or they cling on hard substrates in the inner shelf or in normal marine to hypersaline lagoons and marshes; they rarely can be found in deep-sea records (MURRAY 2006). Recent miliolids prefer waters rich in calcium carbonate (JORISSEN 1988). Borelis is a large, benthic foraminifera with photosynthetic diatom algal symbionts. The recent species are restricted to depths of
5-65 $\mathrm{m}$ in, for example, the Gulf of Aqaba, and to minimum sea-surface temperatures greater than $18^{\circ} \mathrm{C}$ (REISS \& HOTTINGER 1984, LANGER \& HotTinger 2000). Nonkeeled infaunal elphidiids are characteristic species of brackish to hypersaline marshes and lagoons; however, they can also be found in the inner shelf (water depth up to $50 \mathrm{~m}$ ) (MURRAY 2006). Ammonia is widespread in marginal marine environments worldwide and is common in sediments with highly variable mud and organic matter contents, even at low oxygen levels in marsh environments (MURRAY 2006).

Among the ostracods, $\mathrm{Au}$ rila and Urocythereis recently live in great abundance in the infralittoral and uppermost circalittoral zone (water depth up to $40 \mathrm{~m}$ ) of the Black Sea, the Mediterranean, the Eastern Atlantic, and the Indo-Pacific area (e.g., ATHERSUCH 1977, RuIz et al. 1997, KILIÇ 2000, AiELlo et al. 2006, TANAKA 2008). Modern representatives of Aurila, Xestoleberis, and Loxoconcha species mainly live on algae or seagrasses (PURI et al. 1969). Loxoconcha punctatella and Xestoleberis dispar are found in neritic shallow sublittoral, littoral environments in the Mediterranean, Black and Marmara Seas (PERÇIN-PAÇAL et al. 2015). In the present-day Mediterranean Sea, Xestoleberis dispar is a phytal marine species, but it also occurs in hypersaline environments (SCIUTO et al. 2015, KoEHN-ZANINETTI \& TÉTARD 1982). Phlyctenophora occurs in marginal marine estuarine, gulf and lagoonal environments in the IndoPacific Realm (Wouters 1999, HuSSAIN et al. 2004, MisHRA et al. 2019). Recent polycopids have a nektobenthic lifestyle and are found from abyssal ocean depths (KARANOVIC \& BRANDĂO 2012, 2016) to less saline estuarine environments (TANAKA \& TsUKAGOSHI 2010).

Recent Euxinocythere, similarly to Aurila and Loxoconcha, occur in shallow marine sublittoral and littoral environments in the Black Sea (Perçin-PaÇAL et al. 2015). The extant species Heterocypris salina and Darwinula stevensoni are cosmopolitan and are known from all continents. Heterocypris salina lives in saline coastal and inland water bodies coexisting with other halophilic ostracods and tolerate salinities up to 20\%o (MEISCH 2000). The modern species of Darwinula are mostly found in freshwater, although D. stevensoni also tolerates stable, brackish conditions in coastal waters (e.g., Baltic Sea) or saline lakes (NeALE 1988, VAN 
DoNINCK et al. 2003), and is reported to tolerate salinities as high as 15\%o (DE DECKKER 1981). Today, Vestalenula pagliolii occurs in Brazil, where it thrives in riverine pools and lakes, semiterrestrial and/or interstitial habitats and occurs in geographically restricted areas (MARTENS et al. 1997).

\section{Paleoenvironments}

Three main intervals were differentiated in the studied layers of Pécs-Danitzpuszta trench based on the stratigraphic distribution and ecological needs of the identified foraminifera and ostracod taxa, within which further subintervals were designated (Figure 2). The paleocological interpretations are based on the ecology of extant relatives of the studied taxa.

Interval 1 (sample D72) represents the upper Badenian, and it is characterized with the most diverse fossil assemblage within the sedimentary record (Figure 2). The dominance of keeled elphidiids and miliolids among the foraminifera and marine neritic genera (Aurila, Callistocythere, Loxoconcha, Urocythereis, Phlyctenophora, and Xestoleberis) among the ostracods suggests shallow marine, calcium-carbonate rich littoral environment (inner shelf) with water depths up to $50 \mathrm{~m}$. Although several of the identified forms can live today in hypersaline lagoons as well, the high diversity of the microfauna excludes such environmental interpretation. The presence of the large benthic foraminifera Borelis in the assemblage indicates warm seawater, with temperatures higher than $18{ }^{\circ} \mathrm{C}$ (REISS \& HotTinger 1984; LANGER \& HotTINGER 2000). Based on the great abundance of epiphytic dweller foraminifera taxa such as E. aculeatum and E. macellum and phytal ostracods (Aurila, Loxoconcha and Xestoleberis), a rich arborescent algal vegetation is supposed to have been present on the sea bottom. The keeled elphidiids are cromatophore-bearing foraminifers that must have lived in the euphotic zone with well-ventilated conditions. The abundance of thick-shelled ostracods, often with worn valves, and the abundance of echinoderm fragments indicate high energy conditions in the sea bottom. The red algal and bryozoan fragments also support this environmental interpretation.

Interval 2 (samples D69 and D57) yielded only one fish tooth. Carbonate-cemented cylinders around holes were interpreted as rhizoliths (root traces; Figure 2). The Fe-Mn encrusted unconformity on top of bed D57 and the appearance of fossiliferous clays, marls and limestones with upper Sarmatian marine microfossils above the unconformity denote a sharp change in the depositional environment, probably from terrestrial to marine.

Interval 3 (layers D54 to D36) belongs to the upper Sarmatian, suggesting that the area was re-flooded by the sea only during the late Sarmatian.

Subinterval 3a (samples D54 to D41) is characterized by exclusively eurytopic forms and lower diversity than in Interval 1 (Figure 2). The impoverishment of the marine faunal elements is explained by the Badenian-Sarmatian Extinction event (BSEE) caused by the final isolation of the Central Paratethys from the Mediterranean and coeval reconnection with the Eastern Paratethys (HARZHAUSER \& PILlER 2007). Among the elphidiids, non-keeled forms (mainly the specimens of Porosononion granosum) appeared in great abundance due to the unstable environment, e.g., slight fluctuation in salinity or other factors such as food availability. The non-keeled infaunal elphidiids tolerate brackish to hypersaline conditions suggesting marginal marine depositional environments such as a lagoon or a hypersaline marsh. The disappearance of Phlyctenophora and Urocythereis and the dominance of Euxinocythere corroborate the marginal marine conditions. The abundance of the keeled elphidiids and phytal ostracods (Aurila, Loxoconcha and Xestoleberis) implies a rich vegetation on the substrate. The co-occurence of shallow infaunal non-keeled and epiphytic keeled elphidiids suggests mixed assemblages indicating a very differentiated seafloor.

In Subinterval 3b (samples D40 to D37) the faunal composition radically changed (Figure 2). The abundance and diversity of foraminifera and ostracoda decreased. Beside the non-keeled infaunal Porosononion, the specimens of Ammonia cf. confertitesta became dominant. Ammonia cf. confertitesta tolerates a wide range of salinity (10-50\%o) and also occurs in non-marine foraminifera faunas (MURRAY 2006). The ostracod fauna is characterized by nonmarine, freshwater to oligohaline ostracods, such as Darwinula stevensoni, Heterocypris salina, Vestalenula pagliolii, Cyprideis cf. torosa, Fabaeformiscandona sp., and Limnocythere sp. This microfossil assemblage indicates a sudden decrease in salinity (which is also supported by the mollusk fauna represented by Radix, Gyraulus and Theodoxus occurring without the brackish Congeria and cardiids). The interpretation of this phenomenon, however, remains a hard nut to crack. The lithology does not show any sign of increased terrestrial input that the proximity of a river mouth would cause, and the Sarmatian geomorphological position of the outcrop, reconstructed as a tip of a promontory protruding into a wide basin, does not support the idea of a freshened lagoon or coastal marsh either. A more regional cause of the salinity drop, such as a climate change, would have left its mark on the fossil record of a wider region, but we are not aware of such observations. Thus, what we can conclude is only that the euryhaline foraminifera and freshwater-oligohaline ostracods lived together in a brackish water (5-10\%o salinity) habitat.

In Subinterval 3c (sample D36), characteristic Sarmatian eurytopic taxa (non-keeled elphidiids, nonionids, and representatives of the leptocytherid Euxinocythere) replace the non-marine, freshwater-oligohaline species. The low diversity microfossil assemblage with the dominance of infaunal foraminifera (non-keeled elphidiids, nonionids, and bolivinids) and thin-shelled ostracods indicates low-oxygenated environment and/or higher organic content. The latter is supported by the nannoflora, suggesting increasing nutrient supply in this period (ĆORIĆ 2021). 


\section{Conclusions}

The microfossil record of the middle Miocene sedimentary succession of Pécs-Danitzpuszta indicates significant environmental changes through the late Badenian-early Pannonian. The lowermost part of the section belongs to the upper Badenian, with typical Badenian faunal elements indicating stable, normal marine, shallow (inner shelf), warm, well-ventilated environment with relatively high-energy conditions and algal vegetation on the bottom. The overlying layers are devoid of marine microfossils and may indicate terrestrial deposition and subaerial exposure. Following an unconformity, the upper part of the middle Miocene succession belongs to the upper Sarmatian with two distinct biofacies. The lower part and the uppermost layer of the upper Sarmatian are characterized by exclusively eurytopic forms, indicating an unstable and vegetated marginal marine environment with fluctuations in salinity, as well as oxygen and food availability. The middle part of the upper
Sarmatian, however, contains highly euryhaline forams and a unique freshwater to oligohaline ostracod fauna, indicating low salinity. Finally, the disappearance of foraminifera taxa and a complete turnover in the ostracod fauna indicates the boundary between the marginal marine Sarmatian and the brackish lacustrine Pannonian stages (11.6 Ma).

\section{Acknowledgments}

We thank Krisztina Buczkó (Botanical Department of the Natural History Museum, Budapest, Hungary) for her help in taking the SEM images. The research was financially supported by the Hungarian National Research, Development and Innovation Office (NKFIH) project 116618 and by Quartz Ltd., and further supported by the project EFOP 3.6.1-16-2016-00004 of the University of Pécs. This is MTA-MTM-ELTE Paleo contribution No 356.

\section{References - Irodalom}

Agalarova, D. A. 1967: Mikrofauna ponticeskih otlozeni Azerbaidana i Sopregelunih Rajonov. - Nedra, Leningrad, 420 p.

Aiello, G. \& SzCZEChurA, J. 2004: Middle miocene ostracods of the Fore-Carpathian Depression (Central-Paratethys, southwestern Poland). - Bollettino della Societa Paleontologica Italiana 43/1-2, 11-70.

Aiello, G., Barra, D., Coppa, M. G., Valente, A. \& Zeni, F. 2006: Recent infralittoral Foraminiferida and Ostracoda from the Porto Cesareo Lagoon (Ionian Sea, Mediterranean). - Bollettino della Societa Paleontologica Italiana 45/1, 1-14.

Ismail, A. A., Boukhary, M. A. K. \& NABY, A. I. A. 2010: Subsurface stratigraphy and micropaleontology of the Neogene rocks, Nile Delta, Egypt. - Geologia Croatica 63/1, 1-26. https://doi.org/104154/gc.2010.01

ATHERSUCH, J. 1977: The Genus Urocythereis (Crustacea: Ostracoda) in Europe, with particular reference to Recent Mediterranean species. Bulletin of the British Museum (Natural History). - Zoology 32/7, 247-283.

BÁLDI, K. 1999: Taxonomic notes on benthic foraminifera from SW Hungary, Middle Miocene (Badenian) Paratethys. - Acta Geologica Hungarica 42/2, 193-236.

BÁLDI, K. 2006: Paleoceanography and climate of the Badenian (Middle Miocene, 16.4-13.0 Ma) in the Central Paratethys based on foraminifera and stable isotope $\left({ }^{18} \mathrm{O}\right.$ and $\left.{ }^{13} \mathrm{C}\right)$ evidence. - International Journal of Earth Sciences 95/1, 119-142. https://doi.org/ 10.1007/s00531-005-0019-9

BÁldi, K., BenKovics, L. \& SzTANó, O. 2002: Badenian (Middle Miocene) basin development in SW Hungary: subsidence history based on quantitative paleobathymetry of foraminifera. - International Journal of Earth Sciences 91/3, 490-504. https://doi.org/10.1007/ s005310100226

BARdócz B., Bíró E., DANK V., MÉsZÁros L., NÉMETH G. \& ToRmÁSSY I. 1987: A Dunántúli medenceterületek kunsági (pannóniai s. str.) emeletbeli képződményei. [Kunsagian (Pannonian s. str.) formations of the Transdanubian basinal areas]. - A MÁFI Évkönyve 69, 149-166. (in Hungarian)

BAssiouni, M. A. 1979: Brackische und marine Ostrakoden (Cytherideinae, Hemicytherinae, Trachyleberidinae) aus dem Oligozän und Neogen der Türkei. - Geologisches Jahrbuch Reihe B/31, 1-200.

Bekaert, O., Cahuzac, B., Ducasse, O. \& Rousselle, L. 1991: Espèces et populations d'ostracodes a la limite Oligo-Miocéne en Aquitaine: strategie de réponse, microévolution, dans le cadre stratigraphique regional. - Revue de Paléobiologie 10/2,217-227.

Bogdanovich, A. K. 1952: Miliolidy i Peneroplidy, Iskopaemye foraminifery SSSR [Miliolidae and Peneroplidae, Fossil Foraminifera of the USSR]. - Trudy Vsesoyuznogo Neftyanogo Nauchnoissledovatel'skogo Geologorazvedochnnogo Instituta (VNIGRI) 64, 338 p.

BoHn-Havas, M. 1983: Új típusú szarmata Cardiumok a Zsámbéki-medencéből (Budajenő 2. sz. fúrás). (Novel Sarmatian Cardium species from the Zsámbék Basin [borehole Budajenő-2]). - A MÁFI Évi Jelentése 1981-ról, 335-368. (in Hungarian, with English summary)

BotKa, D., Rofrics, N., Katona, L. \& Magyar, I. 2021: Pannonian and Sarmatian mollusks from Pécs-Danitzpuszta, southern Hungary: a unique local faunal succession. - Földtani Közlöny 151/4, 335-362. 
BRANZILĂ, M. I. H. A. I. 2004: Foraminifera assemblages of the backbulge depozone from the Moldavian Platform - the Basarabian. Acta Palaeontologica Romaniae 4, 45-54.

Brestenská, E. 1975: Ostracoden des Egerien. - In: Brestenská, E. (ed.): Chronostratigraphie und Neostratotypen Miozän der Zentralen Paratethys 5, Bratislava: VEDA, Verlag der Slowakischen Akademie der Wissenschaften, $377-411$.

BRESTENSKÁ, E. \& JIŘIČEK, R. 1978: Ostrakoden des Badenien der Zentralen Paratethys. - In: BrestenskÁ, E. (ed.): Chronostratigraphie und Neostratotypen Miozän der Zentralen Paratethys 6, Bratislava: VEDA, Verlag der Slowakischen Akademie der Wissenschaften, 405-439.

Brinkmann, I., Pippèrr, M. \& Reichenbacher, B. 2019: A new well-preserved ostracod fauna from the middle Burdigalian (lower Miocene) of the North Alpine Foreland Basin. - Geobios 56, 65-93. https://doi.org/10.1016/j.geobios.2019.07.005

CAbral, M. C., Colin, J. P. \& CARbonel, P. 2005: Espèces pléistocènes de la famille Darwinulidae Brady et Norman, 1889 (Ostracodes), en Algarve, sud Portugal. - Revue de Micropaléontologie 48/2, 51-62.

Cahuzac, B. \& Poignant, A. 2000: Les foraminifčres benthiques du Langhien du Bassin d'Aquitaine (SW de la France); donnés paléoécologiques et biogéographiques. - Geobios 33/3, 271-300. https://doi.org/10.1016/S0016-6995(00)80158-8

Carbonnel, G. 1969: Les ostracodes du Miocéne Rhodanien. - Documents des laboratoires de géologie de la Faculté des Sciences de Lyon 32/1-2, 1-469.

CARbonnel, G. 1978: L'espéce Cyprideis pannonica MeHEs, 1908 dans la Téthys au Messinien (Miocéne). - Documents des laboratoires de géologie de la Faculté des Sciences de Lyon 72, 79-97.

Carbonnel, G. \& Magné, J. 1977: Microfaunes (Ostracodes et Foraminiferes) du Pliocene de l'Ampurdan (Espagne). - Revista Española de Micropaleontología 9/3, 347-359.

CernajseK, T. 1971: Die Entwicklung und Abgrenzung der Gattung Aurila Pokorný, 1955 im Neogen Österreichs (Vorbericht). Verhandlungen der Geologischen Bundensanstalt 1971/3, 571-575.

CERnAJSEK, T. 1974: Die Ostracodenfaunen der Sarmatischen Schichten in Österreich. - In: BRESTENSKÁ, E. (ed.): Chronostratigraphie und Neostratotypen Miozän der Zentralen Paratethys 4, Bratislava: VEDA, Verlag der Slowakischen Akademie der Wissschaften, 458-491.

Cicha, I. \& Zapletálová, I. 1961: Die Vertreter der Gattung Bolivina (Foraminifera-Protozoa) in Miozän der Westkarpaten. - Sborník Ústředního ústavu geologického, Oddíl paleontologický 28, 115-184.

Cicha, I., RöGL, F., Rupp, C. \& CTYRoKA, J. 1998: Oligocene - Miocene foraminifera of the Central Paratethys. - Abhandlungen der senckenbergischen naturforschenden Gesellschaft 549, Frankfurt am Main: Verlag Waldemar Kramer, 325 p.

ĆORIĆ, S. 2021: Calcareous nannofossils from the middle/upper Miocene succession of Pécs-Danitzpuszta, southern Hungary: cosmopolitan Paratethys and endemic Lake Pannon assemblages. - Földtani Közlöny 151/3, 253-266.

DeCKKER, P. de 1981: Ostracods of athalassic saline lakes: A review. - In: WiLliams, W. D. (ed.): Salt Lakes. Developments in Hydrobiology 5, Springer, Dordrecht, 131-144. https://doi.org/10.1007/978-94-009-8665-7_10

DidKowski, V. J. \& SATANOvSKAJA, Z. N. 1970: Foraminifery miocena Ukrainy. - Paleontologiceskij spravocnik 4, 166 p. (in Russian)

DIECI, G. 1959: I foraminiferi tortoniani di Montegibbio e Castelvetro (Appennino-Modenese). - Palaeontographia Italica 54, 1-113.

Dimiza, M. D., Koukousioura, O., Triantoaphyllou, M. V. \& DermitZaKis, M. D. 2016: Live and dead benthic foraminiferal assemblages from coastal environments of the Aegean Sea (Greece): Distribution and diversity. - Revue de Micropaléontologie 59/1, 19-32.

D’ORBIGNY, A. 1846: Foraminiferes fossiles du Bassin Tertiaire de Vienne (Autriche). Die fossilen Foraminiferen des tertiaeren Beckens von Wien. - Gide et Comp., Paris, 312 p.

Ducasse, O. \& CAhuzac, B. 1996: Évolution de la faune d'ostracodes dans un cadre paléogéographique et interprétation des paléoenviroments au Langhien en Aquitaine. - Revue de Micropaléontologie 39/4, 247-260. https://doi.org/10.1016/S00351598(96)90101-4

Ducasse, O., BeKaert, O. \& Rousselle, L. 1991: Les Loxoconchidae (Ostracodes) a la limite Oligo-Miocéne en Aquitaine: évolution, adaptation et biostratigraphie. - Geobios 24/4, 435-462. https://doi.org/10.1016/S0016-6995(06)80244-5

Dulai, A., Henn, T. \& Sebe, K. 2021: Middle Miocene (Badenian) macroinvertebrates from Pécs-Danitzpuszta (Mecsek Mts., SW Hungary). - Földtani Közlöny 151/4, 329-334.

Dumitriu, S. D., Loghin, S., Dubicka, Z., Melinte-Dobrinescu, M. C., Paruch-KulczycKa, J. \& Ionesi, V. 2017: Foraminiferal, ostracod, and calcareous nannofossil biostratigraphy of the latest Badenian-Sarmatian interval (Middle Miocene, Paratethys) from Poland, Romania and the Republic of Moldova. - Geologica Carpathica 68/5, 419-444. https://doi.org/10.1515/geoca-2017-0028

Faranda, C., Cipollari, P., Cosentino, D., Gliozzi, E. \& Pipponzi, G. 2008. Late Miocene ostracod assemblages from eastern Mediterranean coral reef complexes (central Crete, Greece). - Revue de micropaléontologie 51/4/1-2, 287-308. https://doi.org/10.1016/ j.revmic.2007.06.002

FILIPESCU, S. 1996. Stratigraphy of the Neogene from the western border of the Transylvanian Basin. - Studia Universitatis Babeş-Bolyai, Geologia 41/2/1-2, 3-75.

FILIPESCU, S. 2001: Wielician foraminifera at the western border of the Transylvanian Basin. - Studia Universitatis BabeşBolyai,Geologia 46/2/1-2, 115-123. http://dx.doi.org/10.5038/1937-8602.46.2.10

FiliPESCU, S. \& SiLYe, L. 2008: New Paratethyan biozones of planktonic foraminifera described from the Middle Miocene of the Transylvanian Basin (Romania). - Geologica Carpathica 59/6, 537-544.

Filipescu, S., Silye, L. \& KRÉzSEK, Cs. 2005: Sarmatian micropaleontological assemblages and sedimentary paleoenvironments in the southern Transylvanian Basin. - Acta Palaeontologica Romaniae 5/1-2, 173-179.

Filipescu, S., Wanek, F., Miclea, A., DE Leeuw, A. \& VAsiliev, I. 2011: Micropaleontological response to the changing paleoenvironment across the Sarmatian-Pannonian boundary in the Transylvanian Basin (Miocene, Oarba de Mureş section, Romania). Geologica Carpathica 62/1/1-2, 91-102. https://doi.org/10.2478/v10096-011-0008-9

Filipescu, S., Miclea, A., Gross, M., Harzhauser, M., Zagorsek, K. \& Jipa, C. 2014: Early Sarmatian paleoenvironments in the 
easternmost Pannonian Basin (Borod Depression, Romania) revealed by the micropaleontological data. - Geologica Carpathica 65/1/1-2, 67-81. https://doi.org/10.2478/geoca-2014-0005

FordinÁL, K. \& ZlinsKÁ, A. 1994: Sarmatian Fauna from the Stretava and Kochanovce Formations in the Sečovce Area (Albinovská horka, Eastern Slovakian Basin). - Práce Panstwowego Instytutu Geologicznego 99, 77-82.

FordinÁL, K., ZÁGORSEK, K. \& ZLINSKÁ, A. 2006: Early Sarmatian biota in the northern part of the Danube Basin (Slovakia). - Geologica Carpathica 57/2, 123-130.

FUHRMANN, R. 2012: Atlas quartärer und rezenter Ostrakoden Mitteleuropas. - Altenburger Naturwissenschaftliche Forschungen 15, 1-320.

Garecka, M. \& Olszewska, B. 2011: Correlation of the Middle Miocene deposits in SE Poland and western Ukraine based on foraminifera and calcareous nannoplankton. - Annales Societatis Geologorum Poloniae 81/3, 309-330.

Gebhard, H., Zorn, I. \& Roetzel, R. 2009: The initial phase of the early Sarmatian (Middle Miocene) transgression. Foraminiferal and Ostracod assemblages from an incised valley fill in the Molasse Basin of Lower Austria. - Austrian Journal of Earth Sciences 102/2, 100-119.

GedL, P. \& PERYT, D. 2011: Dinoflagellate cyst, palynofacies and foraminiferal records of environmental changes related to the Late Badenian (Middle Miocene) transgression at Kudryntsi (western Ukraine). - Annales Societatis Geologorum Poloniae 81/3, 331-349.

Gonera, M. 2012: Palaeoecology of the Middle Miocene foraminifera of the Nowy Sącz Basin (Polish Outer Carpathians). - Geological Quarterly 56/1, 107-116.

GöRÖG, Á. 1992: Sarmatian foraminifera of the Zsámbék Basin, Hungary. - Annales Universitatis Scientiarium Budapestinensis de Rolando Eötvös Nominate, Sectio Geologica 29, 31-153.

GrILL, R. 1943: Über mikropaläontologische Gliederungsmöglichkeiten im Miozän des Wiener Becken. - Mitteilungen der Reichsanstalt für Bodenforschung 6, 33-44.

Gross, M. \& Piller, E. W. 2006: Mittelmiozäne Ostracoden aus dem Wiener Becken (Badenium/Sarmatium, Österreich). Österreichische Akademie der Wissenschaften Schriftenreihe der Erdwissenschaftlichen Komissionen. Sonderband 1, 378-425.

Gross, M., Harzhauser, M., Mandic, O., Piller, W. E. \& RöGl, F. 2007: A stratigraphic enigma: the age of the Neogene deposits of Graz (Styrian Basin; Austria). - Joannea Geologie und Paläontologie 9, 195-220.

Hageman, J. 1979: Benthic foraminiferal assemblages from Pleistocene open bay to lagoonal sediments of the western Peloponnesus (Greece). - Utrecht Micropaleontological Bulletins 37, 174 p. https://doi.org/10.1016/S0035-1598(00)90200-9

Hajek-Tadesse, V. \& Prtoljan, B. 2011: Badenian Ostracoda from the Pokupsko area (Banovina, Croatia). - Geologica Carpathica 62/5, 447-461. http://doi.org/10.2478/v10096-011-0032-9

HANGANU, E. 1974: Observations sur l'ostracofaune pontienne de la region comprise entre la vallée du Danube et la vallée du Motru. Revista Espańola de Micropaleontología 6/3, 335-345.

Harries, P. J. \& KnORR, P. O. 2009: What does the 'Lilliput Effect' mean? - Palaeogeography, Palaeoclimatology, Palaeoecology 284/1-2, 4-10. https://doi.org/10.1016/j.palaeo.2009.08.021

Harzhauser, M. \& Piller, W. E. 2007: Benchmark data of a changing sea - palaeogeography, palaeobiogeography and events in the Central Paratethys during the Miocene. - Palaeogeography, Palaeoclimatology, Palaeoecology 253/1-2, 8-31. https://doi.org/ 10.1016/j.palaeo.2007.03.031

Hartmann, G. \& PURI, H. S. 1974: Summary of Neontological and Paleontological Classification of Ostracoda. - Mitteilungen aus dem Hamburgischen Zoologischen Museum und Institut 70, 7-73.

Harzhauser, M. \& Piller, W. E. 2007: Benchmark data of a changing sea. Palaeogeography, Palaeobiogeography and events in the Central Paratethys during the Miocene. Palaeogeography, Palaeoclimatology, Palaeoecology 253, 8-31. https://doi.org/10.1016/ j.palaeo.2007.03.031

Harzhauser, M., Theobalt, D., Strauss, P., Mandic, O., Carnevale, G. \& Piller, W. 2017: Miocene biostratigraphy and paleoecology of the Mistelbach Halfgraben in the northwestern Vienna Basin (Lower Austria). - Jahrbuch der Geologischen Bundesanstalt 157, 57-108.

Harzhauser, M., Mandic, O., Kranner, M., Lukeneder, P., Lern, A., Gross, M., Varnevali, G. \& Jawecki, C. 2018: The Sarmatian/Pannonian boundary at the western margin of the Vienna Basin (City of Vienna, Austria). - Austrian Journal of Earth Sciences 111/1, 26-47. http://doi.org/10.17738/ajes.2018.0003

Hohenegger, J., Ćorić, S. \& Wagreich, M. 2014: Timing of the Middle Miocene Badenian Stage of the Central Paratethys. - Geologica Carpathica 65/1, 55-66. https://doi.org/10.2478/geoca-2014-0004

Horne, D. J., Cohen, A. C. \& Martens, K. 2002: Taxonomy, Morphology and Biology of Quaternary and Living Ostracoda. - In: Holmes, J. A. \& ChIVAS, A. R. (eds): The Ostracoda: applications in Quaternary research. Geophysical monograph, 5-36. https:// doi.org/10.1029/131GM02

Hussain, S. M., Ravi, G., Mohan, S. P. \& RaO, N. R. 2004: Recent benthic Ostracoda from the inner shelf off Chennai, south east coast of India-implication of microenvironments. - Environmental Micropaleontology Microbiology Microbenthology 1, 105-121.

IONESI, B. \& CHINTĂUAN, I. 1975: Studiul ostracodelor din depositele Volhiniene de pe Platforma Moldovenească (sectorul dintre valea siretului şi valea Moldovei). - Dări de seamă ale şedințelor 61 (1973-1974), 3-14.

IONESI, B. \& CHINTĂUAN, I. 1980: Contributii la cunoaşterea faunei de ostracode din Basarabianul Platformei a Moldovaneşti (Regiunea dintre Siret si Moldova). - Analele ştiinţifice ale Universității "Al. I. Cuza" din Iaşi 26/2b, 59-66.

IONESI, B. \& CHINTĂUAN, I. 1985: Ostracofaune des dépôts Besarabiens de la région Văleni (Dobrogea du sud). - Analele ştiințifice ale Universității "Al. I. Cuza" din Iaşi 31/2b, 32-36.

IONESI, V. \& PASCARIU, F. 2011: The relationship between the Sarmatian and Quaternary formations from the Păcurari area (Iaşi, Romania). - Analele ştiințifice ale Universității "Al. I. Cuza" din Iaşi Seria Geologie 57, 5-14.

JÁMBOR, Á., KorPÁs-HódI, M., SzÉLES, M. \& SÜTő-SzEnTAI, M. 1985: Zentrales Mittleres Donaubecken: Bohrung Lajoskomárom Lk-1, 
S-Balaton. - In: PAPP, A., JÁMBor, Á. \& STEInINGer, F. F. (eds): Chronostratigraphie und Neostratotypen: Miozän der Zentralen Paratethys, Band VII. M6, Pannonien (Slavonien und Serbien). Akadémiai Kiadó, Budapest, pp. 204-241.

JANZ, H. \& Vennemann, T. W. 2005: Isotopic composition (O, C, Sr, and Nd) and trace element ratios ( $\mathrm{Sr} / \mathrm{Ca}, \mathrm{Mg} / \mathrm{Ca})$ of Miocene marine and brackish ostracods from North Alpine Foreland deposits (Germany and Austria) as indicatos for palaeoclimate. - Palaeogeography, Palaeoclimatology, Palaeoecology 225, 216-247. https://doi.org/10.1016/j.palaeo.2005.06.012

Jasionowski, M., PerYt, D. \& PerYt, T. M. 2012: Neptunian dykes in the Middle Miocene reefs of western Ukraine: preliminary results. - Geological Quarterly 56/4, 881-894. http://dx.doi.org/10.7306/gq.1066

JIŘIČEK, J. 1972. Problém hranice sarmat/panon ve Vídeňské, Podunajské a Východoslovenské pánvi (Das Problem der Grenze Sarmat/ Pannon in dem Wiener Becken, dem Donaubecken und dem ostslowakischen Becken). - Mineralia Slovaca 4/14, 39-81.

JIŘIČEK, R. 1974: Biostratigraphische Bedeutung der Ostracoden des Sarmats s. str. - In: BRESTENSKA, E. (ed.): Chronostratigraphie und Neostratotypen, Miozän der Zentralen Paratethys 4, Bratislava: VEDA, Verlag der Slowakischen Akademie der Wissenschaften, 434-458.

JIŘIČEK, R. 1983: Redefinition of the Oligocene and Neogene ostracod zonation of the Paratethys. - Miscellanea Micropalaentolologica. Memoire Vol. 18th European Colloquium of Micropaleontological, Bratislava-Praha, 195-236.

JoRISSEN, F., J. 1988: Benthic foraminifera from the Adriatic Sea: principles of phenotypic variation. - Doctoral dissertation, Utrecht University, $174 \mathrm{p}$.

Jovanović, G., Ćorić, S. \& VRABAC, S. 2019: The First evidence of marine Badenian transgression near Koceljeva (central Paratethys, western Serbia). - Geoloski anali Balkanskoga poluostrva 80/1, 1-15.

Karanovic, I. \& Brandăo, S. N. 2012: Review and phylogeny of the Recent Polycopidae (Ostracoda, Cladocopina), with descriptions of nine new species, one new genus, and one new subgenus from the deep South Atlantic. - Marine Biodiversity 42, 329-393. https:// doi.org/10.1007/s12526-012-0116-5

KARAnOVIC, I. \& BRAndăO, S. N. 2016: The genus Polycope (Polycopidae, Ostracoda) in the North Atlantic and Arctic: taxonomy, distribution, and ecology. - Systematics and Biodiversity 14, 198-223. https://doi.org/10.1080/14772000.2015.1131756

KheIL, J. 1967: Die Ostracoden der Karpatischen Serie. - In: CICHA, I. (ed.): Chronostratigraphie und Neostratotypen Miozän der Zentralen Paratethys 3, Verlag: Vydavatelstvo Slovenskej Akademie Vied Bratislava, 213-230.

KILIÇ, M. 2001: Recent ostracoda (Crustacea) fauna of the Black Sea coasts of Turkey. - Turkish Journal of Zoology 25/4, 375-388.

KirCi-Elmas, E. \& Meriç, E. 2016: Benthic foraminiferal fauna of the Sea of Marmara. - In: ÖzsoY, E., ÇAĞATAY, M. N., BALKIS, N. \& ÖZTÜRK, B. (eds): The Sea of Marmara: Marine biodiversity, fisheries, conservation and governance, Turkish Marine Research Foundation, Istanbul, pp. 401-417.

Koehn-ZAninetTi, L. \& TÉTARD, J. 1982: Les Ostracodes des marais salants de Salin-de-Giraud (Sud de la France). - Géologie Méditerranéenne 9/4, 471-478.

Kollmann, K. 1971: Die Ostracoden der Eggenburger Schichtengruppe Niederösterreichs. - In: SENEs, J. (ed.): Chronostratigraphie und Neostratotypen Miozän der Zentralen Paratethys 1, Verlag: Vydavatelstvo Slovenskej Akademie Vied Bratislava, 605-717.

KoreCZ-LAKY I. 1964: Magyarországi szarmata foraminiferák. (Sarmatische Foraminiferen Ungarns.). - Annual Report of the Hungarian Geological Institute of 1964, 475-493.

KORECZ-LAKY I. 1965: A telkibányai szarmata üledékek foraminifera faunája. (Foraminiferen-fauna der Sarmatischen Ablagerungen von Telkibánya). - Annual Report of the Hungarian Geological Institute of 1965, 351-365.

KoreCZ-LAKY I. 1968: A keleti Mecsek miocén Foraminiferái. (Miozäne Foraminiferen des östlichen Mecsek-Gebirges). - A Magyar Állami Földtani Intézet évkönyve 52/1, 229 p.

KoRECZ-LAKY I. 1973: Foraminifera vizsgálatok a Tokaji-hegység miocén képződményeiből. (Examination of the Foraminifera in Miocene rocks of the Tokaj Mountains). - Annual Report of the Hungarian Geological Institute of 1973, 83-119.

KoRECZ-LAKY, I. 1982. Miocene Foraminifera Fauna from the borehole Tengelic-2. - Annales of the Hungarian Geological Institute 65, 151-187.

KorecZ-LaKy, I. \& NAGY-Gellai, Á. 1985: Foraminiferal fauna from the Oligocene and Miocene in the Börzsöny Mountains. - Annals of the Hungarian Geological Institute 68, 1-527.

KovÁCs Z. 2001: A Kolozsvár környéki bádeni és szarmata üledékek biosztratigráfiája. (Studiul biostratigrafic al depozitelor sarmațiene din împrejurimile Clujului). - Collegium Geologicum 2, 67-97.

KováČovÁ, P. \& HudÁČKovÁ, N. 2005: Lower/Middle Badenian foraminiferal associations from the Vienna Basin (Slovak part) and Carpathian Foredeep: Biostratigraphy and paleoecology. - Slovak Geological Magazine 4, 233-248.

KoubovÁ, I. \& HudÁČKOvÁ, N. 2010: Foraminiferal successions in the shallow water Sarmatian sediments from the MZ 93 borehole (Vienna Basin, Slovak part). - Acta Geologica Slovaca 2/1, 47-58.

KôVÁRY J. 1974: Délnyugat-Dunántúl jugoszláv határmenti területén szénhidrogénkutató fúrások által feltárt tengeri üledékek mikrobiofácies-vizsgálata. I. rész: Harmadidőszak (tercier). [Microbiofacies studies of marine sediments explored by hydrocarbon exploration wells along the Yugoslav border of the southwestern part of Transdanubia. I. part: Tertiary]. - Manuscript, Kőolaj- és Földgázbányászati Ipari Kutató Laboratórium, 42 p. (in Hungarian, with 28 photo plates)

Krstić, N. 1972: Ostrakodi kongeriskih slojeva: 10. Loxoconcha. - Bulletin of the Natural History Museum, Belgrade A/27, $243-275$.

KRSTIĆ, N. 1973: Ostrakodi kongeriskih slojeva: 11. Amnicythere. - Radova Instituta geolosko-rudarska istrazivanja ispitivanja nuklearnih drugih mineralnih sirovina 8/8,53-99.

Krstić, N. \& StancheVA, N. 1989: Ostracods of Eastern Serbia and Northern Bulgaria with notice on a Northern Turkey assemblage. In: Stevanovic, P. M., Nevesskaja, L. A., Marinescu, F., SokaČ, A. \& JÁmbor, Á. (eds): Chronostratigraphie und Neostratotypen. Neogen der Westlichen ('Zentrale') Paratethys 8, Pl1, Pontien, 753-819.

LANGER, M. R. 1993: Epiphytic foraminifera. - Marine Micropaleontology 20, 235-265. https://doi.org/10.1016/0377-8398(93)90035-V 
LANGer, M. R. \& Hottinger, L. 2000: Biogeography of selected "larger" foraminifera. - Micropaleontology 46, 105-126. https:// www.jstor.org/stable/1486184

LANGer, M. R., Frick, H. \& SiLK, M. T. 1998: Photophile and sciaphile foraminiferal assemblages from marine plant communities of Lavezzi Islands (Corsica. Mediterranean Sea). - Revue de Paléobiologie 17, 525-530.

LETHIERS, F. \& CRASQUIN-SOLEAU, S. 1988: Comment extraire les microfossiles à tests calcitiques des roches calcaires dures. - Revue de Micropaléontologie 31, 56-61.

Loeblich, A. R. \& TAPPAn, H. 1992: Present status of foraminiferal classification. - In: TAKAYANAgi, Y. \& SaIto, T. (eds): Studies in Benthic foraminifera. Proceedings of the Fourth Symposium on benthic foraminifera, Sendai, 1990, Tokai University Press, Tokyo, pp. 93-102.

ŁuczKowsKa, E. 1974: Miliolidae (Foraminiferida) from Miocene of Poland, part II. Biostratigraphy, paleoecology and systematics. Acta Paleontologica Polonica 19/1, 1-176.

MARKs, P. 1951: A Revision of the Smaller Foraminifera from the Miocene of the Vienna Basin. - Contributions from the Cushman Foundation for Foraminiferal Research 2/2,33-73.

Martens, K., Rossetti, G. \& Fuhrmann, R. 1997: Pleistocene and Recent species of the family Darwinulidae Brady et Norman, 1889 (Crustacea, Ostracoda) in Europe. - Hydrobiologia 357, 99-116. https://doi.org/10.1023/A:1003130702375

MARTINI, E. 1971: Standard Tertiary and Quaternary calcareous nannoplankton zonation. - In: Farinacci A. (Ed.): Proceedings II Planktonic Conference, Rome 2, 739-785.

MéHEs, Gy. 1908: Adatok Magyarország pliocén Ostracodáinak ismeretéhez II. Az alsópannóniai emelet Darwinulidae-i és Cytheridaei. - Földtani Közlöny 38, 61-65.

MeIsch, C. 2000: Freshwater Ostracoda of Western and Central Europe. - In: Schwoerbel, J. \& Zwick, P., (eds): Süßwasserfauna von Mitteleuropa 8/3, 1-522. Spektrum Akademischer Verlag, Heidelberg, Berlin 522.

Melis, R., Furlani, S., Antonioli, F., Biolchi, S., Degrassi, V. \& MeZgec, K. 2012: Sea level and paleoenvironment during roman times inferred from coastal archaeological sites in Trieste (northern Italy). - Alpine and Mediterranean Quaternary 25/1, 41-55.

Meriç, E., Avsar, N., Görmüs, M. \& Bergin, F. 2004: Twin and triplet forms of Recent benthic foraminifera from the eastern Aegean Sea, Turkish coast. - Micropaleontology 50/3, 297-300.

Milker, Y. \& SchmiedL, G. 2012: A taxonomic guide to modern benthic shelf foraminifera of the western Mediterranean Sea. Palaeontologia electronica 15/2,1-134.

MischKe, S., SchudAck, U., Bertrand, S. \& Leroy, S. A. 2012: Ostracods from a Marmara Sea lagoon (Turkey) as tsunami indicators. - Quaternary International 261, 156-161.

Mischke, S., Ashrenazi, S., Almogi-Labin, A. \& Goren-Inbar, N. 2014: Ostracod evidence for the Acheulian environment of the ancient Hula Lake (Levant) during the early-mid Pleistocene transition. - Palaeogeography, Palaeoclimatology, Palaeoecology 412, 148-159.

Mishra, R., Hussain, S. M. \& NAZEer, M. N. 2019: Distribution of ostracoda and foraminifera from sediments of Chilika Lagoon, Odisha, East Coast of India. - Journal of the Palaeontological Society of India 64/1, 115-120.

Morigi, C., Jorissen, F. J., Fraticelli, S., Horton, B. P., Principi, M., Sabbatini, A., Capotondi, L., Curzi, P. V. \& Negri, A. 2005: Benthic foraminiferal evidence for the formation of the Holocene mud-belt and bathymetrical evolution in the central Adriatic Sea. Marine Micropaleontology 57/1-2, 25-49. https://doi.org/10.1016/j.marmicro.2005.06.001

Mostafawi, N. 1986: Pleistozäne Ostracoden aus der Nikolaos-Formation von Ost-Kos, Griechenland. - Senckenbergiana lethaea 67/14, 275-303.

Murray, J. W. 1991: Ecology and Palaeoecology of Benthic Foraminifera. - Longman Scientific \& Technical, Essex, England, 397 p.

MurRAY, J. W. 2006: Ecology and applications of benthic foraminifera. - Cambridge: Cambridge University Press, 318 p.

NÁÑEZ, C. \& MALumián, N. 2019: Foraminíferos miocenos en la cuenca Neuquina, Argentina: implicancias estratigráficas y paleoambientales. - Andean geology 46/1, 183-210. http://dx.doi.org/10.5027/andgeov46n1-3142

Nazik, A., Tuerkmen, I., Koc, C., Aksoy, E., AvŞAR, N. \& YaYIK, H. 2008: Fresh and Brackish Water Ostracods of Upper Miocene Deposits, Arguvan/Malatya (Eastern Anatolia). - Turkish Journal of Earth Sciences 17/3, 481-495.

NeAle, J. W. 1988: Ostracodes and paleosalinity reconstructions. - In: DE DECKKER, P., Colin, J. P. \& PeYPouQUeT, J.-P. (eds): Ostracoda in Earth Sciences. Elsevier, Amsterdam, 125-155.

OblaK, K. 2007: Most abundant Middle Miocene rotaliinas (suborder Rotaliina, Foraminifera) of Kozjansko (Eastern Slovenia). Geologija 50/2, 293-322

Olteanu, R. 1989: La faune d'ostracodes ponties du Bassin Dacique. - In: Malez, M. \& Stevanovic, P. (eds): Chronostratigraphie und Neostratotypen, 8, Verlag der Jugoslawischen Akademie der Wissenschaften und Künste und der Serbischen Akademie der Wissenschaften und Künste, Zagreb, 722-752.

OlteAnu, R. 1998: Orthogenesis and orthoselection, Leptocythere lineages in brackish-water Neogene (Ostracoda). - Revista Roumania Géologie 42, 141-153.

OlteAnu, R. 2001: Hemicytherinae subfamily (Ostracoda, Crustacea) and its species in Paratethys brackish-water facieses (Neogene, Carpathian areas). Their morphology and taxonomy. - Studii i cercetări de Geologie 46, 71-110.

Olteanu, R. 2011: Atlas of the Pannonian and Pontian Ostracods from the Eastern Area of the Pannonian Basin. - Geo-Eco-Marina 17/2011, 135-177. https://doi.org/10.5281/zenodo.45062

Ozsvárt, P. 2007: Middle and Late Eocene benthic foraminiferal fauna of the Hungarian Paleogene Basin: systematics and paleoecology. - Hantken Press, Budapest, 129 p.

Palcu, D. V., Tulbure, M., Bartol, M., Kouwenhoven, T. J. \& Krijgsman, W. 2015: The Badenian-Sarmatian Extinction Event in the Carpathian foredeep basin of Romania: Paleogeographic changes in the Paratethys domain. - Global and Planetary Change 133, 346-358. https://doi.org/10.1016/j.gloplacha.2015.08.014 
PAPP, A. 1963: Die biostratigraphische Gliederung des Neogens im Wiener Becken, Die Elphidien im Neogen des Wiener beckens, Genus Ammonia BRÜNNICH, 1772 (= Rotalia partim), Die biostratigraphischen Grundlagen der Gliederung des Neogens im Wiener Becken. - Mitteilungen der Geologischen Gesellschaft in Wien 56/1, 255-289.

PAPP, A. 1974: Die Entwicklung des Sarmats in Österreich. - In: BrestensKá, E. (ed.): Chronostratigraphie und Neostratotypen, Miozän der Zentralen Paratethys 4, 75-77. Bratislava: VEDA, Verlag der Slowakischen Akademie der Wissenschaften.

PAPP, A. \& SENEŠ, J. 1974: Grundzüge der Entwicklung der Fauna und die Biozonen im Sarmatien s. str. der Zentralen Paratethys. - In: BRESTENSKÁ, E. (ed.): Chronostratigraphie und Neostratotypen Miozän der Zentralen Paratethys 4, 41-44.

Papp, A., Cicha, I., Seneš, J. \& Steininger, F. 1978: M4 - Badenien (Moravien, Wielicien, Kosovien). - Chronostratigraphie und Neostratotypen, Miozän der Zentralen Paratethys 6, 594 p.

PARLAK, D. \& NAZIK, A. 2016: Ostracods of the Mediterranean (The Gulf of Antalya) and the Aegean Sea (Ayvalik and Kuşadasi) and their biogeographical distributions. - Bulletin of the Mineral Research and Exploration 152, 63-83.

PARUCH-KUlCZYCKA, J. 1992: Malzoraczki srodkowego miocenu (badenu) z otwour Broniszowice (SW Polska). - Kwartalnik Geologiczny 36/2, 259-280. (in Polish)

Paruch-Kulczycka, J. \& Szczechura, J. 1996: Ostracoda. - In: Malinowska, L. \& Piwocki, M. (ed.): Budowa geologiczna Polski 3, $727-742$.

Perçin-PaÇal, F., Altinsaçli, S. \& Balkis, H. 2015: An updated checklist of recent marine and coastal brackish water ostracods (Crustacea Ostracoda) in Turkey. - Journal of Entomology and Zoology Studies 3/3, 20-33.

PerYt, D. 2013: Foraminiferal record of the Middle Miocene climate transition prior to the Badenian salinity crisis in the Polish Carpathian Foredeep Basin (Central Paratethys). - Geological Quarterly 57/1, 141-164. https://doi.org/10.7306/gq.1080

Peryt, D., GedL, P. \& Peryt, T. M. 2020: Marine transgression (s) to evaporite basin: The case of middle Miocene (Badenian) gypsum in the Central Paratethys, SE Poland. - Journal of Palaeogeography 9, 1-18. https://doi.org/10.1186/s42501-020-00062-0

Pezelu, D., MAndic, O. \& Ćorić, S. 2013: Paleoenvironmental dynamics in the southern Pannonian Basin during initial Middle Miocene marine flooding. - Geologica Carpathica 64/1, 81-100. http://doi.org/10.2478/geoca-2013-0006

PezelJ, D., Sremac, J. \& Bermanec, V. 2016: Shallow-water benthic foraminiferal assemblages and their response to the palaeoenvironmental changes - example from the Middle Miocene of Medvednica Mt. (Croatia, Central Paratethys). - Geologica Carpathica 67/4, 329-345. http://doi.org/10.1515/geoca-2016-0021

PietrZEnIUK, E. 1973: Neue Callistocythere-Arten (Ostracoda) aus dem Unteren Sarmat des Tokajer Gebirges (Nördliche Ungarische VR). - Zeitschrift für Geologische Wissenschaften 1, 703-733.

PIPÍK, R. \& Bodergat, A. M. 2004: Euxinocythere (Ostracoda, Cytheridae, Leptocytherinae) du Miocène supérieur du Bassin de Turiec (Slovaquie): taxonomie et paléoécologie. - Revue de Micropaléontologie 47, 36-52.

Pipík , R., Fordinál, K., Slamková, M., Starek, D. \& ChalupovÁ, B. 2004: Annotated checklist of the Pannonian microflora, evertebrate and vertebrate community from Studienka, Vienna Basin. - Scripta Facultatis Scientiarum Naturalium Universitatis Masarykianae Brunensis, Geology 31-32, 47-54.

POPESCU, GH. 1995. Contributions to the knowledge of the Sarmatian foraminifera of Romania. - Romanian Journal of Paleontology 76, 85-98.

Popov, S. V., Rögl, F., Rozanov, A.Y., Steininger, F. F., Scherba, I. G. \& KovaC, M. 2004: Lithological-Paleogeographic maps of the Paratethys (10 maps Late Eocene to Pliocene). - Courier Forschungsinstitut Senckenberg 250, 1-46.

Puri, H. S., Bonaduce, G., \& Gervasio, A. M. 1969: Distribution of Ostracoda in the Mediterranean. - In: Neale, J. W. (ed.): The Taxonomy, Morphology and Ecology of Recent Ostracoda, Edinburgh, 356-412.

Raffi, I., Wade, B. S. \& PÄlike, H. 2020: The Neogene Period. - In: Gradstein, F. M., OgG, J. G., Schmitz, M. D. \& OgG, G. M. (eds): Geologic Time Scale 2020. Elsevier, 1141-1215. https://doi.org/10.1016/B978-0-12-824360-2.00029-2

ReIss, Z. \& HotTINGER, L. 1984: Shell producers in the water column. - In: ReISs, Z. \& HotTingER, L. (eds): The Gulf of Aqaba, Springer, Berlin, Heidelberg, 89-138.

Reuss, A. E. 1850: Die fossilen Entomostraceen des österreichischen Tertiärbecken. - Haidinger's Naturwissenschaftliche Abhandlungen 31, 1-92.

Roslim, A., Briguglio, A., Kocsis, L., Ćorić, S. \& Gebhardt, H. 2019: Large rotaliid foraminifera as biostratigraphic and palaeoenvironmental indicators in northwest Borneo: An example from a late Miocene section in Brunei Darussalam. - Journal of Asian Earth Sciences 170, 20-28. https://doi.org/10.1016/j.jseaes.2018.10.019

RöGL, F. 1969: Die miozäne Foraminiferenfauna von Laa an der Thaya in der Molassenzone on Niederösterreich. - Mitteilungen der Geologischen Gesellschaft in Wien 61/1968, 63-123.

RöGL, F. 1998: Palaeogeographic Considerations for Mediterranean and Paratethys Seaways (Oligocene to Miocene). - Annalen des Naturhistorischen Museums in Wien 99A (1998), 279-310.

Rögl, F., Ćorić, S., Harzhauser, M., Jimenez-Moreno, G., Kroh, A., Schultz, O., Wessely, G. \& Zorn, I. 2008: The Middle Miocene Badenian stratotype at Baden-Sooss (Lower Austria). - Geologica Carpathica 59/5, 367-374.

Ruiz, F., GonZÁlez-Regalado, M. L. \& MuÑoz, J. M. 1997: Multivariate analysis applied to total and living fauna: seasonal ecology of recent benthic Ostracoda off the North Cádiz Gulf coast (southwestern Spain). - Marine Micropaleontology 31/3-4, 183-203. https://doi.org/10.1016/S0377-8398(96)00060-6

Saftić, B., Velić, J., Sztanó, O., Juhász, Gy. \& Ivković, Z. 2003: Tertiary Subsurface Facies, Source Rocks and Hydrocarbon Reservoirs in the SW Part of the Pannonian Basin (Northern Croatia and South-Western Hungary). - Geologia Croatica 56, $101-122$.

SAlel, T., Bruneton, H. \& LefÈvre, D. 2016: Ostracods and environmental variability in lagoons and deltas along the north-western Mediterranean coast (Gulf of Lions, France and Ebro delta, Spain). - Revue de Micropaléontologie 59/4, 425-444.

SChÜTZ, K., HARZHAUSER, M., RÖGL, F., ĆORIĆ, S. \& GAlović, I. 2007: Foraminiferen and Phytoplankton aus dem unteren Sarmatium des südlichen Wiener Beckens (Petronell, Niederöstereich). - Jahrbuch der Geologischen Bundesanstalt 147, 449-488. 
Sciuto, F., Rosso, A., SAnfilippo, R. \& Di Martino, E. 2015: Ostracods from mid-outer shelf bottoms of the Ciclopi Islands Marine Protected Area (Ionian Sea, Eastern Sicily). - Bollettino della Società Paleontologica Italiana 54/2, 131-145. https://doi.org/ 10.4435/BSPI.2015.09

SEBE, K. 2021: Structural features in the Miocene sediments of the Pécs-Danitzpuszta sand pit (SW Hungary). - Földtani Közlöny 151/4, $411-422$.

Sebe, K., Csillag, G., Dulai, A., Gasparik, M., Magyar, I., Selmeczi, I., Szabó, M., Sztanó, O. \& Szuromi-Korecz, A. 2015: Neogene stratigraphy in the Mecsek region. In: Bartha, I-R., Kriván, Á., MagYar, I. \& Sebe, K. (eds): Neogene of the Paratethyan Region. 6th Workshop on the Neogene of Central and South-Eastern Europe. - An RCMNS Interim Colloquium. Programme, Abstracts, Field Trip Guidebook. 2015.05.31-06.03, Orfü. Hungarian Geological Society, Budapest, 102-124.

Sebe, K., Selmeczi, I., Szuromi-Korecz, A., Hably, L., Kovács, Á. \& Benkó, Zs. 2019: Miocene syn-rift lacustrine sediments in the Mecsek Mts. (SW Hungary). - Swiss Journal of Geosciences 112, 83-100., https://doi.org/10.1007/s00015-018-0336-1

Sebe, K., Kovačić, M., Magyar, I., Krizmanić, K., ŠPelić, M., Bigunac, D., Sütő-Szentai, M., Kovács, Á., Szuromi-Korecz, A., BaKRač, K., HajeK-TAdesse, V., Troskot-Čorbić, T. \& SzTANó, O. 2020: Correlation of upper Miocene-Pliocene Lake Pannon deposits across the Drava Basin, Croatia and Hungary. - Geologia Croatica 73/3, 177-195. https://doi.org/10.4154/gc.2020.12

SEbe, K., KonRÁD, Gy. \& SzTANó, O. 2021: An exceptional surface occurrence: the middle to upper Miocene succession of PécsDanitzpuszta (SW Hungary). - Földtani Közlöny 151/3, 235-252.

SeKo, M., PipÍk, R. \& Dolakova, N. 2012: Early Badenian ostracod assemblage of the Židlochovice stratotype (Carpathian Foredeep, Czech Republic). - Open Geosciences 4/1, 111-125. https://doi.org/10.2478/s13533-011-0049-8

SILYE, L. 2015: Sarmatian foraminiferal assemblages from southern Transylvanian Basin and their significance for the reconstruction of depositional environments. - Cluj University Press, Cluj, 229 p.

SoKAČ, A. 1967: Pannonische und Pontische Ostracoden fauna des südwestlichen Teiles des Pannonischen Becken. - Carpatho-Balkan Geological Association, 8th Congress, Belgrade, Rep. Stratigrafia, 445-453.

SoKAČ, A. 1972: Pannonian and Pontian Ostracoda Fauna of Mt. Medvednica. - Palaentologia Jugoslavica 11, 73 p.

SoKaČ, A. 1989: Pontian Ostracod fauna in the Pannonian Basin. - In: MAlez, M. \& Stevanovic, P. (eds): Chronostratigraphie und Neostratotypen 8, Verlag der Jugoslawischen Akademie der Wissenschaften und Künste und der Serbischen Akademie der Wissenschaften und Künste, Zagreb, 672-721.

StAncheva, M. 1962: Ostracodna fauna ot neogena v severozapadna Bulgariia. I. tortonskii ostracodi. - Travaux sur la Géologie de Bulgaria, series Paléontologie 4, 5-75.

STANCHEVA, M. 1963: Ostracodna fauna ot neogena v severozapadna Bulgariia. II: sarmatskii ostracodi. - Travaux sur la Géologie de Bulgaria, series Paléontologie 5, 1-75.

StANCHEVA, M. 1972: Sarmatian ostracods from north-eastern Bulgaria. - Bulletin of the Geological Institute, series Paleontology 21, 103-128.

StAnChEVA, M. 1990: Upper Miocene ostracods from northern Bulgaria-Geologica Balcanica series operum singulorum 5, 7-102.

Steininger, F. F. \& RöGL, F. 1984: Paleogeography and palinspastic reconstruction of the Neogene of the Mediterranean and Paratethys. - Geological Society, London, Special Publications 17/1, 659-668. https://doi.org/10.1144/GSL.SP.1984.017.01.52

SteInINGer, F. F. \& Wessely, G. 2000: From the Tethyan Ocean to the Paratethys Sea: Oligocene to Neogene Stratigraphy, Paleogeography and Paleobiogeography of the circum-Mediterranean region and the Oligocene to Neogene Basin evolution in Austria. - Mitteilungen der Österreichischen Geologischen Gesellschaft 92, 95-116.

Stojanova, V. \& Petrov, G. 2014: Foraminifer fauna in paleogene sediments at Rabrovo and Dedeli sites in the Stojanovae ValandovoGevgelia basin, Republic of Macedonia. - Geologica Macedonica 28/1, 45-53.

SucIU, A.-A. 2005: Preliminary data on the Sarmatian deposits from Lombi Hill (Popeşti locality) Northwest from Cluj-Napoca. Analele ştiințifice ale Universității "Al. I. Cuza" din Iaşi, Geologie 51, 121-130.

SuzIN, A. V. 1956: Ostracodi tretichnih otlozhenii Severnava Predkavkazia. - Groznemsk. ordena Krasnaveznameni neft. Institut Gostoptechnizdat, 1-184.

Szabó, M., Kocsis, L., Bosnakoff, M. \& Sebe, K. 2021: A diverse Miocene fish assemblage (Chondrichthyes and Osteichthyes) from the Pécs-Danitzpuszta sand pit (Mecsek Mts., Hungary). - Földtani Közlöny 151/4, 363-410.

SzCZECHURA, J. 1982: Middle Miocene foraminiferal biochronology and ecology of SE Poland. - Acta Palaeontologica Polonica 27/14, 3-44.

SzCZECHURA, J. 2000: Age and evolution of depositional enviroments of the supra-evaporitic deposits in the northern, marginal part of the Carpathian Foredeep: micropaleontological evidence. - Geological Quarterly 44/1, 81-100.

SzCZECHURA, J. 2006: Middle Miocene (Badenian) ostracods and green algae (Chlorophyta) from Kamienica Nawojowska, Nowy Sacz Basin (Western Carpathians, Poland). - Geologica Carpathica 57/2, 103-122.

SZÉLES, M. 1982: Pannonian ostracoda fauna from the borehole Tengelic 2. - Annals of Hungarian Geological Institute 65, $235-289$.

SzUROMI-KoreCZ, A. \& SzEGÓ, É. 2001: Data for knowledge of foraminifera and ostracoda microfauna of Kovácsszénája (SW-Hungary) - Folia Komloensis 10, 51-74.

TANAKA, G. 2008: Recent benthonic ostracod assemblages as indicators of the Tsushima Warm Current in the southwestern Sea of Japan. - Hydrobiologia 598, 271-284.

TANAKA, H. \& Tsukagoshi, A. 2010: Two new interstitial species of the genus Parapolycope (Crustacea: Ostracoda) from central Japan. - Zootaxa 2500/1, 39-57. https://doi.org/10.11646/zootaxa.2500.1.2.

Temelkov, B. K. 2008: Ecological characteristics of the foraminiferal fauna (Protozoa: Foraminifera) of the Bulgarian South Black Sea area. - Acta Zoologica Bulgarica 2, 275-282.

ter Borgh, M., Vasiliev, J., Stoica, M., Knežević, S., Matenco, L., Krijgsman, W., Rundić, L. \& Cloetingh, S. 2013: The isolation 
of the Pannonian Basin (Central Paratethys): New constraints from magnetostratigraphy and biostratigraphy. - Global and Planetary Change 103, 99-118. https://doi.org/10.1016/j.gloplacha.2012.10.001

ter Borgh, M., Stoica, M., Donselaar, M., Matenco, L. \& Krijgsman, W. 2014: Miocene connectivity between the Central and Eastern Paratethys: Constraints from the western Dacian Basin. - Palaeogeography, Palaeoclimatology, Palaeoecology $412,45-67$. http://dx.doi.org/10.1016/j.paleo.2014.07.016

То́тн, E. 2004: Sarmatian ostracods from Budapest (Hungary). - Hantkeniana 4, Shallow Tethys 6 Symposium proceedings, 25-29 August 2003, 129-159.

TóтH, E. 2008: Sarmatian (Middle Miocene) ostracod fauna from the Zsámbék Basin, Hungary. - Annales Universitatis Scientiarum Budapestinensis de Rolando Eötvös Nominatae, Sectio Geologica 36, 101-151.

То́тн E. 2009: Ôskörnyezeti változások a Középső-Paratethysben a szarmata folyamán a mikrofauna ôslénytani és geokémiai vizsgálata alapján. [Changements paléoenvironnementaux dans la Paratéthys Centrale pendant le Sarmatien (Miocène moyen): étude paléontologique de microfaunes et analyses géochimiques]. - Doktori értekezés, ELTE Ốslénytani Tanszék, Université Claude Bernard Lyon 1, Budapest/Lyon, 153 p.

Tóth, E. \& GöröG, Á. 2008: Sarmatian foraminifera fauna from Budapest (Hungary). - Hantkeniana 6, 187-217.

Tuncer, A., TunoĞLu, C., AYdAr, E., YILMAZ, İ. Ö., GüMüş, B. A. \& ŞEN, E. 2019: Holocene paleoenvironmental evolution of the Aclgöl paleo maar lake (Nevşehir, Central Anatolia). - Mediterranean Geoscience Reviews 1/2, 255-269

Valchev, B. \& Stojanova, V. 2016: Benthic foraminiferal morphogroups from the Paleogene of the Republic of Macedoniacharacterization and paleoecological significance. - Review of the Bulgarian Geological Society 77/2-3, 3-21.

Van BaAk, C. G., Vasiliev, I., Stoica, M., Kuiper, K. F., Forte, A. M., Aliyeva, E. \& Krijgsman, W. 2013: A magnetostratigraphic time frame for Plio-Pleistocene transgressions in the South Caspian Basin, Azerbaijan. - Global and Planetary Change 103, $119-134$. https://doi.org/10.1016/j.gloplacha.2012.05.004

VAn Doninck, K., Schön, I., MARTEns, K. \& GodDeERIs, B. 2003: The life-cycle of the asexual ostracod Darwinula stevensoni (Brady \& Robertson, 1870) (Crustacea, Ostracoda) in a temporate pond. - Hydrobiologia 500/1, 331-340. https://doi.org/10.1023/ A:1024656920904

VENGLINSKY I. V. 1958: Miocene foraminifera from the Transcarpathian area [Foraminiferi miocenu Zakarpatja]. - Vidavictvo Akademia Nauk Ukrainskoi RSR, Kiev, 1-246 (in Ukrainian)

VenglinsKy, I. V. 1975: Foraminifery i biostratigrafia miocenovih otlozenij zakarpatskovo progiba. - Vidavictvo Akademia Nauk Ukrainskoi RSR, Kiev, 263 p.

Voloshinova, N. A. 1952. Nonionidae. - In: Voloshinova, N. A. \& Dain, L. G. (eds): Noniony, Cassidulinidy I Hilostomellidy. Trudy VNIGRI 63, 13-75.

VoICU, G. 1981: Upper Miocene and recent mysid statoliths in Central and Eastern Paratethys. - Micropaleontology 27/3, $227-244$. https://doi.org/10.2307/1485236

von Fichtel, L. \& von Moll, J. P. C. 1798: Testacea Microscopica alique minuta ex Generibus Argonauta et Nautilus. - Anton Pichler, Wien, $123 \mathrm{p}$.

VRSALJKo, D. 1999: The Pannonian palaeoecology and biostratigraphy of molluscs from Kostanjek-Medvednica Mt., Croatia. - Geologia Croatica 52/1, 9-27.

Wouters, K. 1999: Two new species of the genus Phlyctenophora Brady, 1880 (Crustacea, Ostracoda) from the Indo-Pacific realm. Bulletin de l'Institut Royal des Sciences Naturelles de Belgique, Biologie 69, 83-92.

Yokes, M. B., Meriç, E., Avşar, N., Barut, I., Tas, S., Eryilmaz, M., Dinçer, F. \& Bircan, C. 2014: Opinions and comments on the benthic foraminiferal assemblage observed around the mineral submarine spring in Kuşadas (Aydin, Turkey). - Marine Biodiversity Records 7, 1-17. https://doi.org/10.1017/S1755267214000840

ZelenkA, J. 1985: Badenian Ostracoda from Podivin (Vienna Basin - Southern Moravia). - Věstník Ústředního ústavu geologického 60/4, 245-248.

ZelenkA, J. 1990: A review of the Sarmatian ostracoda of the Vienna basin. - In: Whatley, R. \& MaYbURY, C. (eds): Ostracoda and Global Events, London, British Micropaleontological Society Publication, Chapman and Hall, 263-269.

Zheng, S. Y., Cheng, T., WANG, X. \& Fu, Z. 1978: The Quaternary Foraminifera of the Dayuzhang Irrigation area, Shandong Province, and a preliminary attempt at an interpretation of its depositional environment. - Studia Marina Sinica 13, 72-78.

ZlinsKá, A. 1997: Biostratigraphy of Sarmatian sediments from the Kosicka kotlina depression on the basis of Foraminifers. - Slovak Geological Magazine 3-4, 285-298.

ZLINSKÁ, A. 1998: Microbiostratigraphy of the Badenian sediments in the East Slovakian Basin on the Foraminifera study basis. - Zemny Plyn a Nafta 43, 11-153.

ZlinskÁ, A. \& FordinÁL, K. 1995: A Spodnosarmatská fauna zo stretavského súvrstvia z okolia Slanskej Huty (východoslovenská panva). - Práce Panstwowego Instytutu Geologicznego 100, 71-75. (in Slovak)

ZoRN, I. 1998: Ostracoda aus dem Karpat (Unter-Miozän) des Korneuburger Beckens (Niederösterreich). - Beiträge zur Paläontologie 23, 175-271.

ZoRN, I. 2004: Ostracoda from the lower Badenian (middle Miocene) Grund Formation (Molasse Basin, Lower Austria). - Geologica Carpathica 55/2, 179-189.

Manuscript recieved: 30/07/2021 


\section{Plate I - I. tábla}

Badenian microfossils from the studied exploratory trench in Pécs-Danitzpuszta: 1: Callistocythere canaliculata (Reuss), RV in lateral view, layer D72, scale bar: $250 \mu \mathrm{m}$; 2-3: Aurila cicatricosa (Reuss), 2: LV in lateral view, 3: C in right view, layer D72, scale bar: $250 \mu \mathrm{m}$; 4: Urocythereis kostelensis (Reuss), LV in lateral view, layer D72, scale bar: $250 \mu \mathrm{m}$; 5: Loxoconcha punctatella (Reuss), LV in lateral view layer D72, scale bar: $200 \mu \mathrm{m}$; 6: Senesia cinctella (REuss), C in right view, layer D72, scale bar: $250 \mu \mathrm{m}$; 7: Xestoleberis tumida (Reuss), RV in lateral view, layer D72, scale bar: $250 \mu \mathrm{m}$; 8: Xestoleberis dispar MuelLeR, C in left view, layer D72, scale bar: 250 m; 9: Borelis sp., SV, layer D72, scale bar: $200 \mu \mathrm{m}$; 10: Heterolepa dutemplei (D’ORBIGNY), UV, layer D72, scale bar: $500 \mu \mathrm{m}$; 11: Cycloforina contorta

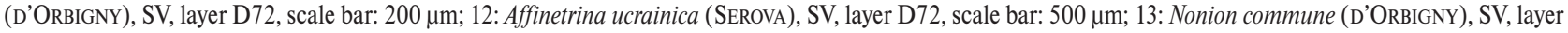
D72, scale bar: 500 um; 14: Elphidium crispum (LinNÉ), SV, scale bar: 500 um; 15: Textularia sp., layer D72; 16: Pyrgo subsphaerica (D'ORBIGNY), layer D72; 17: Asterigerinata planorbis (D’ORBIGNY), layer D72; 18: Heterolepa dutemplei (D'ORBIGNY), layer D72; 19: echinoid spine, layer D72; 20: sponge spicule, layer D72; 21: red algae fragment, layer D72; 22: serpulid worm burrow, layer D72

Abbreviations: $\mathrm{LV}=$ left valve, $\mathrm{RV}=$ right valve, $\mathrm{C}=$ carapace, $\mathrm{SV}=$ side view, $\mathrm{UV}=$ umbilical view

Badeni mikrofossziliák a pécs-danitzpusztai homokbányában ásott kutatóárokból: 1: Callistocythere canaliculata (REUSS), RVoldalnézetben, D72 réteg, méretarány: 250 um; 2-3: Aurila cicatricosa (REUSS), 2: LV oldalnézetben, 3: C jobb oldali nézetben, D72 réteg, méretarány: 250 um; 4: Urocythereis kostelensis (REUSS), LV oldalnézetben, D72 réteg, méretarány: $250 \mu m$; 5: Loxoconcha punctatella (REUSS), LV oldalnézetben, D72 réteg, méretarány: $200 \mu$ um; 6: Senesia cinctella (REUSS), C jobb oldali nézetben, D72 réteg, méretarány: $250 \mu \mathrm{m}$; 7:Xestoleberis tumida (REUSS), RV oldalnézetben, D72 réteg, méretarány: 250 $\mu$ m; 8: Xestoleberis dispar MUELLER, $C$ in bal oldali nézetben, $D 72$ réteg, méretarány: $250 \mu \mathrm{m}$; 9: Borelis $s p ., S V, D 72$ réteg, méretarány: $200 \mu \mathrm{m}$; 10: Heterolepa dutemplei (D'ORBIGNY), UV, D72 réteg,

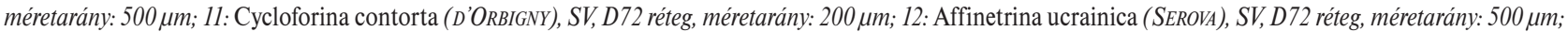
13: Nonion commune (D'ORBIGNY), SV, D72 réteg, méretarány: $500 \mu m$; 14: Elphidium crispum (LINNÉ), SV, méretarány: $500 \mu m$; 15: Textularia sp., D72 réteg; $16:$ Pyrgo subsphaerica (D'ORBIGNY), D72 réteg; 17: Asterigerinata planorbis (D'ORBIGNY), D72 réteg; 18: Heterolepa dutemplei (D'ORBIGNY), D72 réteg; 19: tengerisüntüske, D72 réteg; 20: szivacstü, $D 72$ réteg; 21: vörösalga-töredék, D72 réteg; 22: féregjárat, D72 réteg

Röviditések: $\mathrm{LV}=$ bal teknő, $\mathrm{RV}=$ jobb teknő, $\mathrm{C}=$ kettősteknő, $\mathrm{SV}=$ oldalnézet, $\mathrm{UV}=$ köldökoldali nézet

\section{Plate II - II. tábla}

Sarmatian ostracods from the studied exploratory trench in Pécs-Danitzpuszta: 1: Amnicythere tenuis (Reuss), RV in lateral view, layer D50, scale bar: $200 \mu$ m; $2-$ 3: Amnicythere cernajseki STANCHEVA, 2: LV in lateral view, 3: RV in lateral view, layer D38, scale bar: $200 \mu \mathrm{m}$; 4-6: Euxinocythere (Euxinocythere) praebosqueti (SuZIN), 4: ecophenotype, LV in lateral view, layer D36, scale bar: $250 \mu \mathrm{m}$; 5: RV in lateral view, layer D36, scale bar: $200 \mu \mathrm{m}$; 6: LV in lateral view, layer D50, scale bar: $200 \mu \mathrm{m}$; 7: Euxinocythere (Euxinocythere) naca (MÉHES), RV in lateral view, layer D50, scale bar: $200 \mu \mathrm{m}$; 8-9: Cyprideis pokorny JiŘIČEK, 8: male, RV in lateral view, 9: female, RV in lateral view, layer D38, scale bar: $250 \mu \mathrm{m}$; 10: Cyprideis sp., layer D38, scale bar: $250 \mu \mathrm{m}$; 11: Hemicytheria omphalodes (Reuss), juvenile, RV in lateral view, layer D36, scale bar: $200 \mu \mathrm{m} ; 12-13$ : Aurila notata (Reuss), 12: RV in lateral view, 13: LV in lateral view, layer D50, scale bar: 500 $\mu \mathrm{m}$; 14-15: Loxoconcha kochi MéHEs, 14: LV in lateral view, 15: RV in lateral view, layer D50, scale bar: 250 m; 16: Loxoconcha laeta STANCHEVA, LV in lateral view, layer D54, scale bar: $200 \mu \mathrm{m}$; 17: Loxoconcha porosa MéHES, RV in lateral view, layer D54, scale bar: $200 \mu \mathrm{m}$; 18: Loxocauda sp., layer D38, scale bar: 250 $\mu \mathrm{m}$; 19-20: Loxocorniculum hastatum (REUss), 19: LV in lateral view, 20: RV in lateral view, layer D36, scale bar: $250 \mu \mathrm{m}$; 21: Darwinula stevensoni (BRADY \& RoBERTSON), C in right view, layer D 40, scale bar: $250 \mu \mathrm{m}$; 22-23: Vestalenula pagliolii (PINTo \& KotZiAN), 22: RV in lateral view, 23: C in left view, layer D38, scale bar: $200 \mu \mathrm{m}$; 24: Fabaeformiscandona? sp. juv., RV in lateral view, layer D38, scale bar: $200 \mu \mathrm{m}$; 25: Limnocythere sp., LV in lateral view, layer D38, scale bar: $200 \mu \mathrm{m}$; 26 : Heterocypris salina (BRADY), C in left view, layer D40, scale bar: $500 \mu \mathrm{m}$

Abbreviations: $\mathrm{LV}=$ left valve, $\mathrm{RV}=$ right valve, $\mathrm{C}=$ carapace

Szarmata kagylósrákok a pécs-danitzpusztai homokbányában ásott kutatóárokból: 1: Amnicythere tenuis (REUSS), RV oldalnézetben, D50 réteg, méretarány: 200 um; 2-3: Amnicythere cernajseki STANCHEVA, 2: LV oldalnézetben, 3: RV oldalnézetben, D38 réteg, méretarány: $200 \mu m$; 4-6: Euxinocythere (Euxinocythere) praebosqueti (SUzIN), 4: ökofenotípus, LV oldalnézetben, D36 réteg, méretarány: $250 \mu \mathrm{m}$; 5: RV oldalnézetben, D36 réteg, méretarány: $200 \mu m$; 6: LV oldalnézetben, D50 réteg, méretarány: $200 \mu \mathrm{m}$; 7: Euxinocythere (Euxinocythere) naca (MÉHES), RV oldalnézetben, D50 réteg, méretarány: $200 \mu$ m; 8-9: Cyprideis pokorny JIŘIČEK, 8: hím, RV oldalnézetben, 9: nöstény, RV oldalnézetben, D38 réteg, méretarány: $250 \mu \mathrm{m}$; 10: Cyprideis sp., D38 réteg, méretarány: 250 um; 11: Hemicytheria omphalodes (REuSs), juvenilis, $R V$ oldalnézetben, D36 réteg, méretarány: $200 \mu \mathrm{m} ; 12-13$ : Aurila notata (REUSS), 12: RV oldalnézetben, 13: LV oldalnézetben, D50 réteg, méretarány: 500 um; 14-15: Loxoconcha kochi MÉHES, 14: LV oldalnézetben, 15: RV oldalnézetben, D50 réteg, méretarány: $250 \mu \mathrm{m}$; 16: Loxoconcha laeta STANCHEVA, LV oldalnézetben, D54 réteg, méretarány: $200 \mu \mathrm{m}$; 17: Loxoconcha porosa MÉHES, RV oldalnézetben, D54 réteg, méretarány: $200 \mu$ m; 18: Loxocauda sp., D38 réteg, méretarány: 250 4 m; $19-20$ : Loxocorniculum hastatum (REUSS), 19: LV oldalnézetben, 20: RV oldalnézetben, D36 réteg, méretarány: 250 um; 21: Darwinula stevensoni (BRADY \& ROBERTSON), C jobb oldali, D40 réteg, méretarány: $250 \mu \mathrm{m} ; 22$-23: Vestalenula pagliolii (PINTO \& KoTZIAN), 22: RV oldalnézetben, 23: C baloldali nézetben, D38 réteg, méretarány: 200

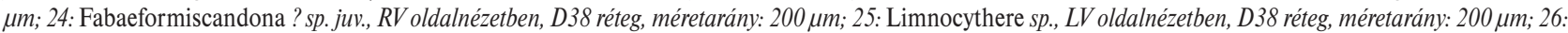
Heterocypris salina (BRADY), C bal oldali nézetben, D40 réteg, méretarány: $500 \mu \mathrm{m}$

Röviditések: $L V=$ bal teknö, $R V=$ jobb teknö, $C=$ carapace

\section{Plate III - III. tábla}

Sarmatian foraminifers and other microfossils from the studied exploratory trench in Pécs-Danitzpuszta: 1: Articulina sp. indet., fragmented specimen, layer D41,

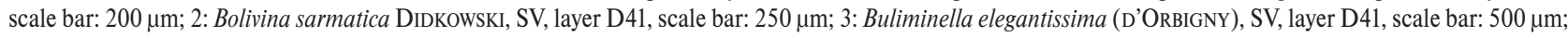
4: Ammonia cf. confertitesta ZHENG, UV, layer D41, scale bar: $200 \mu \mathrm{m}$; 5: Porosononion granosum (D’ORBIGNY), SV, layer D54, scale bar: $250 \mu \mathrm{m}$; 6: Elphidium hauerinum (D'ORBIGNY), SV, layer D54, scale bar: $200 \mu \mathrm{m}$; 7-8: Elphidium aculeatum (D’ORBIGNY), SV, layer D54, scale bar: 250 $\mu$ m; 9: Porosononion granosum (D’ORBIGNY), layer D37; 10: Vestalenula pagliolii (PINTO \& KotZIAN), layer D38; 11-12: Fabaeformiscandona ? sp. juv., layer D38; 13: Calcisphaera-like large algal cyst, layer D35; 14: Mysid statolith, layer D35.

Abbreviations: $\mathrm{SV}=$ side view, $\mathrm{UV}=$ umbilical view

Szarmata foraminiferák és egyéb mikrofossziliák a pécs-danitzpusztai homokbányában ásott kutatóárokból: 1: Articulina sp. indet., töredékes példány, D41 réteg, méretarány: $200 \mu m$; 2: Bolivina sarmatica DIDKOWSKI, SV, D41 réteg, méretarány: $250 \mu \mathrm{m}$; 3: Buliminella elegantissima (D'ORBIGNY), SV, D41 réteg, méretarány: $500 \mu$ m; 4: Ammonia cf. confertitesta ZHENG, UV, D41 réteg, méretarány: $200 \mu \mathrm{m}$; 5: Porosononion granosum (D'ORBIGNY), SV, D54 réteg, méretarány: $250 \mu m$; 6: Elphidium hauerinum (D'ORBIGNY), SV, D54 réteg, méretarány: $200 \mu \mathrm{m}$; 7-8: Elphidium aculeatum (D'ORBIGNY), SV, D54 réteg, méretarány: 250 $\mu m$; 9: Porosononion granosum (D'ORBIGNY), D37 réteg; 10: Vestalenula pagliolii (PINTO \& KotzIAN), D38 réteg; 11-12: Fabaeformiscandona ? sp. juv., D38 réteg; 13: Calcisphaerához hasonló nagyméretü alga ciszta, D35 réteg; 14: Misidae statolith, D35 réteg.

Rövidítések: $\mathrm{SV}=$ oldalnézet, $\mathrm{UV}=$ köldökoldali nézet 
Plate I - I. tábla
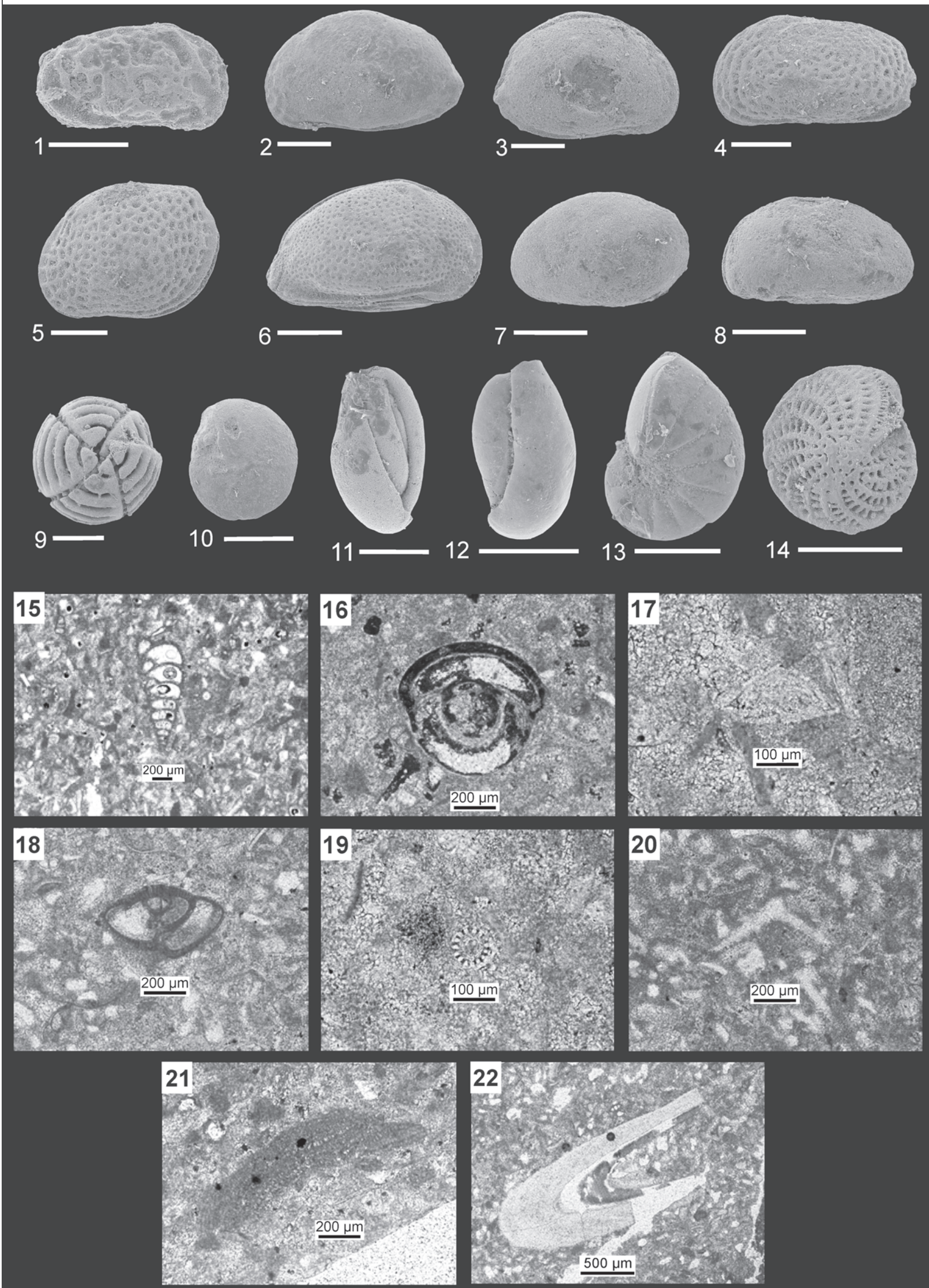
Plate II - II. tábla

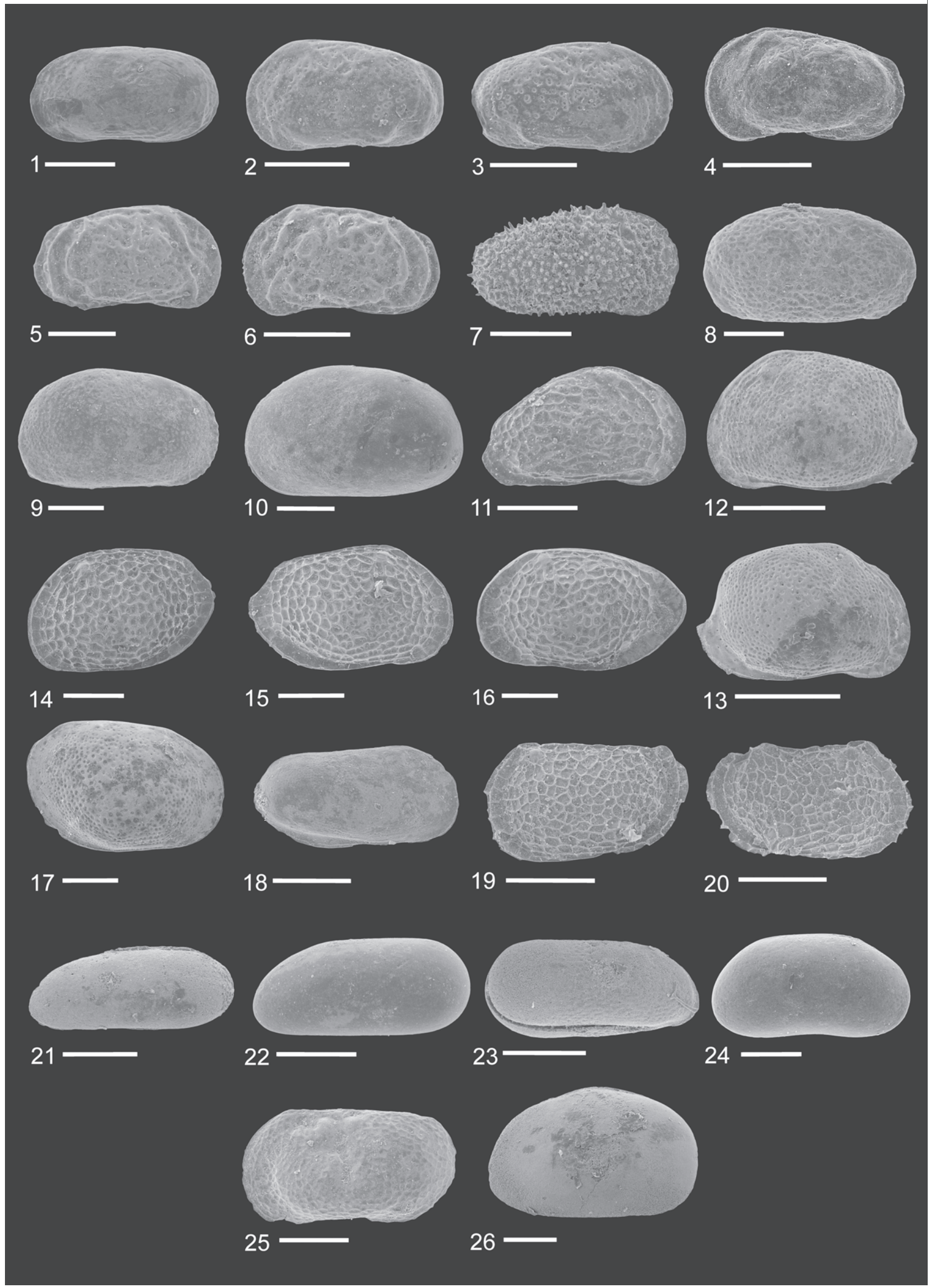




\section{Plate III - III. tábla}

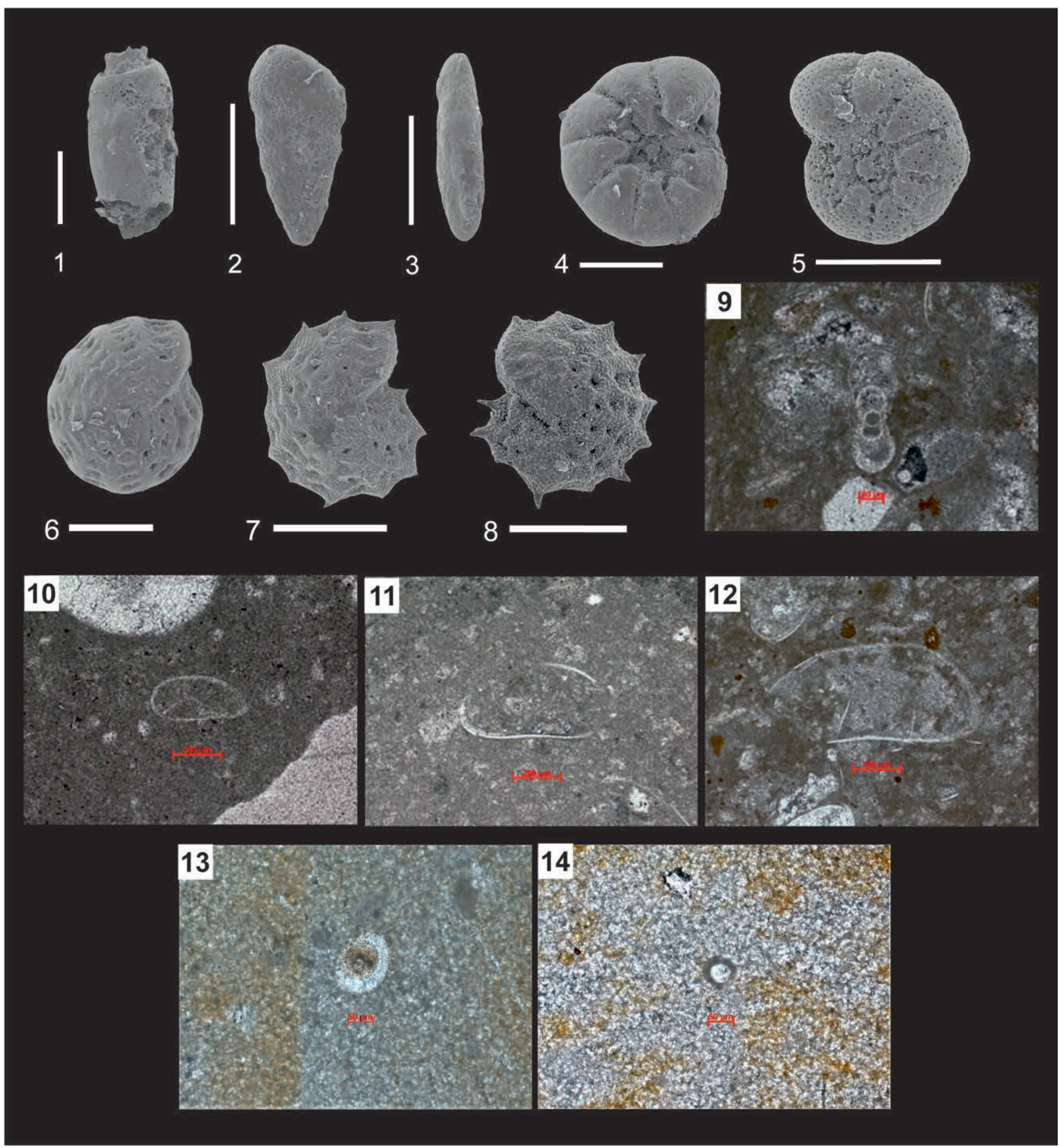




\section{Appendix}

\section{Systematic Palaeontology}

The specimens of foraminifers and ostracods are reposited in the Laboratory of MOL Plc., Exploration and Production Division (Budapest, Hungary).

\section{Foraminifera}

Higher classification of the foraminifera follows that of LOEBLICH \& TAPPAN (1992). Abbreviations: L: length, B: breadth, D: diameter and Th: thickness.

\section{Phylum Protista}

Subphylum Sarcodina ScHMARDA, 1871

Class Foraminifera J.J. LEE, 1990

Order Miliolida LANKESTER, 1885

Suborder Miliolina Delage \& Heruard, 1896

Superfamily Milioloidea EHRENBERG, 1839

Family Hauerinidae SCHWAGER, 1876

Subfamily Hauerininae SCHWAGER, 1876

Genus Cycloforina LuCZKOWsKA, 1972

Cycloforina contorta (D'ORBIGNY, 1846)

Plate I, fig. 11

1846 Quinqueloculina contorta n. sp. D'OrBIGNY, p. 298, pl. 20, figs 4-6.

2008 Cycloforina contorta (D’ORBIGNY) - TóTH \& GöRÖG, p. 196, pl. 1, fig. 1. (cum syn.)

2012 Cycloforina contorta (D'ORBIGNY) - GONERA, fig. 2/M.

2012 Cycloforina contorta (D'ORBIGNY) - MILKER \& SCHMIEDL, pp. 53-54, fig. 14/6.

2014 Cycloforina contorta (D'ORBIGNY) - YOKES et al., fig. 8/2.

2016 Cycloforina contorta (D'ORBIGNY) - LEI \& LI, pp. 98-99, fig. 6. 2016 Cycloforina contorta (D’ORBIGNY) - KIRCI-Elmas \& MERIÇ, fig. $3 / 8$.

Dimensions: $\mathrm{L}=530-540 \mu \mathrm{m}, \mathrm{B}=400-410 \mu \mathrm{m}, \mathrm{Th}=220$ $240 \mu \mathrm{m}$

Stratigraphic range and geographic distribution: Miocene: Carpathian Foredeep and Transcarpathian Basin, Ukraine (Bogdanowich 1952, DidKowsky \& SATANOvSKAJA 1970); Badenian: Carpathian Foredeep, Poland (LuCZKowsKA 1974; GONERA 2012), Vienna Basin, Austria (D'ORBIGNY 1846); Badenian to Sarmatian: Mecsek Mts, Hungary (KoRECZ-LAKY 1968); Sarmatian: Zsámbék Basin and Budapest, Hungary (GöRÖG 1992, TóTH \& GöRÖG 2008). Recently widely distributed over the world.
Subfamily Miliollinellinae VeLLA, 1957

Genus Affinetrina LUCZKOWSKA, 1972

Affinetrina ucrainica (SEROVA, 1952)

Plate I, fig. 12

1952 Miliolina ucrainica n. sp. SEROVA in BogdANOWICH, p. 104, pl. 8 , fig. 2.

1992 Affinetrina ucrainica (SEROVA) - GÖRÖG, pp. 79-80, pl. 6, figs 1-3. (cum syn.)

2007 Affinetrina ucrainica (SEROVA) - ScHÜTZ et al., p. 453, pl. 2, fig. 2.

2012 Affinetrina ucrainica (SEROVA) - MiLKER \& SCHMIEDL, p. 61, fig. 16/11-13.

2015. Affinetrina ucrainica (SEROVA) - SILYE, p. 111, pl. 1, figs 4-5.

Dimensions: $\mathrm{L}=500-530 \mu \mathrm{m}, \mathrm{B}=200-300 \mu \mathrm{m}, \mathrm{Th}=160$ $220 \mu \mathrm{m}$

Stratigraphic range and geographic distribution: Upper Badenian: Carpathian Foredeep, Poland (LuCZKowsKA 1974); Upper Badenian - Sarmatian: Transcarpathian Basin and Carpathian Foredeep, Ukraine (DiDKOwSKY \& SATANOVSKAJA 1970); Lower Sarmatian: Vienna Basin, Austria (SchÜTZ et al. 2007); Sarmatian: Moesian Platform, Bulgaria (Stancheva 1960), Transylvanian Basin, Romania (SiLYE 2015); Zsámbék Basin, Hungary (GöRÖG 1992). Recently widely distributed in the Mediterranean Sea.

Genus Pyrgo Defrance, 1824

Pyrgo subsphaerica (D'ORBIGNY, 1839)

Plate I, fig. 16 (thin section)

1839 Biloculina subsphaerica n. sp. D'ORBIGNY, p. 162, pl. 8, figs 25-27.

1974 Pyrgo subsphaerica (D’ORBIGNY) - LUCZKOWSKA, pp. 118119 , pl. 22, figs $4 a$, b.

2008 Pyrgo subsphaerica (D'ORBIGNY) - DE ARAÚJO \& MACHADO, pl. 1 , fig. 3 .

Dimensions: $\mathrm{B}=660 \mu \mathrm{m}$ (other dimensions are not examined)

Stratigraphic range and geographic distribution: Upper Badenian: Carpathian Foredeep, Poland (LuCzKOwsKA 1974). Recently widely distributed in the Mediterraen Sea, Caribbean Sea and Atlantic Ocean. 
Order Buliminida FuRSENKO, 1958

Superfamily Bolivinoidea GLAESSNER, 1937

Family Bolivinidae GLAESSNER, 1937

Genus Bolivina D'OrBIGNY, 1839

\section{Bolivina sarmatica DIDKOWSKY, 1959}

Plate III, fig. 2

1970 Bolivina sarmatica DIDKOWSKY - DIDKOWSKY \& SATANOVSKAJA, p. 144, pl. 82, fig. 9. (holotype)

2008 Bolivina sarmatica DiDKOWSKY - TóTH \& GöRÖG, p. 198, pl. 1, fig. 12. (cum syn.)

2011 Bolivina sarmatica DiDKOWSKY - GARECKA \& OLSZEWSZKA, fig. $6 / \mathrm{e}$.

2011 Bolivina sarmatica DIDKOWSKY - FILIPESCU et al., fig. 5/3. 2014 Bolivina sarmatica DIDKOWSKY - FILIPESCU et al., fig. 5/19. 2015 Bolivina sarmatica DiDKOWSKY - SILYE, p. 129, pl. 4, fig. 17. 2017 Bolivina sarmatica DIDKOWSKY - DUMITRIU et al., fig. 13/p. 2018 Bolivina sarmatica DiDKOWSKY - HARZHAUSER et al., fig. $5 / 10$.

Dimensions: $\mathrm{L}=150-160 \mu \mathrm{m}, \mathrm{B}=90-95 \mu \mathrm{m}$

Stratigraphic range and geographic distribution: Sarmatian: Moldavian Plateau (DiDKOWSKY \& SATANOvSKAJA 1970), Transcarpathian Basin, Carpathian Foredeep, Volhynian-Podolian Plateau, Ukraine (VENGLINSKY 1975), Western Carpathians (CichA \& ZAPLETALOvÁ 1961), easternmost Pannonian and Transylvanian Basins, Romania (FILIPESCU 1996; FILIPESCU et al. 2011, 2014), Zsámbék Basin and Budapest, Hungary (GöröG 1992, TóTH \& GöRÖG 2008), Carpathian Foredeep, Poland and Romania (GARECKA \& OlszewszKa 2011, Dumitriu et al. 2017), Vienna Basin, Austria (HARZHAUSER et al. 2018).

Superfamily Buliminoidea JoNES, 1875

Family Buliminellidae HOFKER, 1951

Genus Buliminella Cushman, 1911

\section{Buliminella elegantissima (D'ORBIGNY, 1839)} Plate III, fig. 3

1839 Bulimina elegantissima n. sp. D'ORBIGNY, p. 51, pl. 7, figs 1314.

2004 Buliminella elegantissima (D'ORBIGNY) - VILELA et al., fig. $4 / 4$.

2008 Buliminella elegantissima (D’ORBIGNY) - TóTH \& GöRÖG, pp. 198-199, pl. 2, figs 2-4. (cum syn.)

2011 Buliminella elegantissima (D'ORBIGNY) - FILIPESCU et al., fig. $5 / 10$.

2014 Buliminella elegantissima (D'ORBIGNY) - FILIPESCU et al., fig. $6 / 13$.

Dimensions: $\mathrm{L}=230-320 \mu \mathrm{m}, \mathrm{D}=90-100 \mu \mathrm{m}$

Stratigraphic range and geographic distribution: Sarmatian: Black Sea Depression, Ukraine, Moldavian Plateau (DidKOWsky \& SATANovskaja 1970), Zsámbék Basin and Budapest, Hungary (GöRÖG 1992, TóTH \& GÖRÖG 2008), easternmost Pannonian and Transylvanian Basins, Romania (FILIPESCU et al. 2011, 2014). Recently widely distributed over the world.
Superfamily Asterigerinoidea D'ORBIGNY, 1839

Family Asterigerinatidae REISS, 1963

Genus Asterigerinata REISs, 1963

\section{Asterigerinata planorbis (D'ORBIGNY, 1846)}

Plate I, fig. 17 (thin-section)

1846 Asterigerina planorbis n. sp. D'ORBIGNY, p. 225, pl. 11, figs $1-3$.

1985 Asterigerina planorbis D'ORBIGNY - PAPP \& SCHMID, pl. 66, figs 9-14.

1985 Asterigerina planorbis D'ORBIGNY - KORECZ-LAKY \& NAGYGELLAI, pl. 158, figs 1-4.

1998 Asterigerinata planorbis (D’ORBIGNY) - CicHA et al., pl. 64, figs 8-10.

1998 Asterigerinata planorbis (D’ORBIGNY) - ZLINSKÁ, pl. 8, figs 10-11.

2007 Asterigerinata planorbis (D’ORBIGNY) - SCHÜTZ et al., p. 457, pl. 4, fig. 6.

2010 Asterigerina planorbis D'ORBIGNY - IsMAIL et al., pl. 4, figs 4-5. 2012 Asterigerinata planorbis (D'ORBIGNY) - GONERA, fig. 4/c.

2013 Asterigerinata planorbis (D’ORBIGNY) - PEZELJ et al., fig. $6 / 17$.

2016 Asterigerinata planorbis (D'ORBIGNY) - PEZELJ et al., fig. 5/A-H.

2014 Biasterigerina planorbis (D'ORBIGNY) - TER BORGH et al., fig. 5/31-32.

2019 Asterigerinata planorbis (D’ORBIGNY) - JovANOVIĆ et al., pl. 1 , figs $\mathrm{f} / 6, \mathrm{~g} / 5, \mathrm{~h} / 6$.

2020 Asterigerinata planorbis (D'ORBIGNY) - PERYT et al., fig. 4/h.

Dimensions: $\mathrm{D}=250-350 \mu \mathrm{m}$

Stratigraphic range and geographic distribution: Kiscellian: Börzsöny Mts, Hungary (KoRECZ-LAKY \& NAGYGellai 1985); Badenian: Vienna Basin, Austria (D'OrBIGNY 1846), East-Slovakian Basin (ZLINSKÁ 1998), Dacian Basin, Romania (TER BorgH et al. 2014), Mt Majevica, Bosnia and Herzegovina (PEZELJ et al. 2013, 2016); Koceljeva area, Western Serbia (Jovanović et al. 2019); Carpathian Foredeep, Poland (Gonera 2012, PERYT et al. 2020), North-Croatian Basin, Croatia (PEZELJ et al. 2016); Lower Sarmatian: Vienna Basin, Austria (ScHüTZ et al. 2007); Pliocene: Nile Delta, Egypt (IsMAIL et al. 2010).

Superfamily Nonionoidea SCHULTZE, 1854

Family Nonionidae ScHULTZE, 1854

Subfamily Nonioninae ScHULTZE, 1854

Genus Nonion MonTFORT, 1808

\section{Nonion commune (D’ORBIGNY, 1846)}

Plate I, fig. 13

1798 Nautilus scapha n. sp. FICHTEL \& Moll, p. 105, pl. 19, figs d-f. 1846 Nonionina communis D'ORBIGNY - D'ORBIGNY, p. 106, pl. 5 , figs 7-8.

2008 Nonion commune (D’ORBIGNY) - TóTH \& GöRÖG, pp. 22203, pl. 2, figs 14-18. (cum syn.)

2009 Nonion commune (D'ORBIGNY) - GEBHARDT et al., pl. 2, fig. 39. 2010 Nonion commune (D'ORBIGNY) - KoubOvÁ \& HudAČKOVÁ, pl. 1, fig. 15.

2012 Nonion commune (D’ORBIGNY) - Ferrer García \& BlÁZQUEZ MORILLA, fig. 4/6. 
2012 Nonion commune (D'ORBIGNY) - GonERA, fig. 4/e.

2013 Nonion commune (D'ORBIGNY) - PERYT, fig. 4/F.

2013 Nonion commune (D'ORBIGNY) - PEZELJ et al., fig. 6/18.

2014 Nonion commune (D'ORBIGNY) - FILIPESCU et al., fig. 6/7.

2019 Nonion commune (D'ORBIGNY) - JovanOVIĆ et al., pl. 1, figs

$\mathrm{f} / 14, \mathrm{~g} / 6, \mathrm{~h} / 3$.

2019 Nonion commune (D'ORBIGNY) - RosLIM et al., fig. 4/33-36.

Dimensions: $\mathrm{D}=350-370 \mu \mathrm{m}, \mathrm{Th}=130-160 \mu \mathrm{m}$

Stratigraphic range and geographic distribution: Karpatian: Molasse Basin, Austria (RöGL 1969); Badenian: Vienna Basin, Austria and Slovakia (D'ORBIGNY 1846, KoVÁČOvÁ \& HudÁČKOVÁ 2005), Carpathian Foredeep, Poland (SzCZechura 1982, Peryt 2013); Volhynian-Podolian Plateau, Carpathian Foredeep, Transcarpathian Basin, CrimeaCaucasus region and Kuban Lowland, Ukraine and Russia (Voloshinova 1952, DidKowsky \& Satanovskaja 1970), Slovenia (OBlak 2007), Mt Majevica, Bosnia and Herzegovina (Pezelu et al. 2013), Koceljeva area, Western Serbia (Jovanović et al. 2019); Badenian to Sarmatian: Mecsek Mts, Tokaj Mts and SW-Hungary, Budapest (KORECZ-LAKY 1968, 1973, 1982; BÁlDI 1999; TóTH \& GöRÖG 2008), Appenines, Italy (DIECI 1959); Sarmatian: E-Slovakian Basin, Slovakia (ZlinsKá 1997, Koubová \& HudAČKOvá, 2010), Vienna Basin, Austria (SCHÜTZ et al. 2007, GEBHARDT et al. 2009), easternmost Pannonian Basin, Romania (FIlIPESCU et al. 2014); Upper Miocene: Ambug Hill, Borneo (RosLim et al. 2019). Recently widely distributed over the world.

Superfamily Rotalioidea EHRENBERG, 1839

Family Rotaliidae EHRENBERG, 1839

Subfamily Ammoniinae SAIDOVA, 1981

Genus Ammonia BRÜNNICH, 1772

Ammonia cf. confertitesta ZHENG, 1978 Plate III, fig. 4

Dimensions: $\mathrm{D}=250-450 \mu \mathrm{m}$

Remaks: The studied specimens are very similar (mainly the spiral side of the test) to the holotype described by ZHENG (1978) however the last chamber of the studied specimens in most cases is missing.

Family Elphidiidae GALLOWAY, 1933

Subfamily Elphidiinae GALLOWAY, 1933

Genus Elphidium MONTFORT, 1808

\section{Elphidium aculeatum (D'ORBIGNY, 1846) Plate III, figs 7-8}

1846 Polystomella josephina n. sp. D’OrBIGNY, p. 130, pl. 6, figs 25-26.

1846 Polystomella aculeata n. sp. - D'ORBIGNY, p. 131, pl. 6, figs 27-28.

1995.Elphidium aculeatum (D'ORBIGNY) - POPESCU, p. 94, pl. 7, figs 4-7.

2004 Elphidium aculeatum (D'ORBIGNY) - BRÂNZILĂ, pl. 4, fig. 5. 2004 Elphidium aculeatum (D'ORBIGNY) - MERIÇ et al., pl. 32, figs 5-8. 2005 Elphidium aculeatum (D'ORBIGNY)-GOLDBECK et al., pl. 1, fig. 12. 2008 Elphidium aculeatum (D’ORBIGNY) - TóTH \& GöRÖG, pp. 204-205, pl. 3, figs 5-6. (cum syn.)
2010 Elphidium josephinum (D'ORBIGNy) - KoubOVA \& HudAČKOVA, pl. 1, fig. 26.

2011 Elphidium aculeatum (D'ORBIGNY) - GEDL \& PERYT, pl. 1, fig. 9/F, I-K.

2012 Elphidium aculeatum (D'ORBIGNY) - Aloulou et al., pl. 1, fig. 13.

2012 Elphidium aculeatum (D'ORBIGNY) - MiLKER \& SCHMIEDL, p. 119, fig. 27/5-6.

2012 Elphidium aculeatum (D'ORBIGNY) - GONERA et al., fig. 4/K. 2012 Elphidium aculeatum (D'ORBIGNY) - Melis et al., pl. 1, fig. 1.

2012 Elphidium aculeatum (D'ORBIGNY) - PERYT \& JASIONOWSKI, fig. $4 / C, D, L, M$.

2012 Elphidium aculeatum (D'ORBIGNY) - JASIONOWSKI et al., fig. 12/A, B, D, E.

2013 Elphidium aculeatum (D'ORBIGNY) - TER BORGH et al., fig. 6, 8-9.

2014 Elphidium josephium (D'ORBIGNY) - FILIPESCU et al., fig. 7/10. 2014 Elphidium aculeatum (D'ORBIGNY) - YOKES et al., fig. 11/8.

2015 Elphidium aculeatum (D'ORBIGNY) - SILYE, p. 150, pl. 8, figs $1-2,4$.

2017 Elphidium aculeatum (D'ORBIGNY) - DUMITRIU et al., fig. $11 / \mathrm{Q}, \mathrm{R}$.

2020 Elphidium aculeatum (D'ORBIGNY) - PERYT et al., fig. 3/h.

Dimensions: $\mathrm{D}=450-600 \mu \mathrm{m}, \mathrm{Th}=200-350 \mu \mathrm{m}$.

Stratigraphic range and geographic distribution: Badenian: Carpathian Foredeep, Poland and Ukraine (Gedl \& Peryt 2011, Gonera et al. 2012, Peryt et al. 2020); Late Badenian to Sarmatian: Volhynian-Podolian Plateau, Moldavian Plateau, Moldavia and Carpathian Foredeep, Ukraine (VENGLINSKY 1958; DidKowSKY \& SATANOVSKAJA 1970, BRÂNZILĂ 2004), Crimea-Caucasus region, South-Caspian Depression, Russia and Azerbaijan (Voloshinova 1952); Sarmatian: Carpathian Foredeep, Poland, Romania and Ukraine (SzCZECHURA 1982, 2000; JASIONOWSKI et al. 2012; DumitriU et al. 2017), Vienna Basin, Austria and Slovakia (MARKs 1951, PAPP 1963; SchüTZ et al. 2007; Koubova \& HudAČKOVA 2010), Danube Basin and East-Slovakian Basin, Slovakia (BREsTenská 1974; ZlinsKá 1997), Tokaj Mts, Mecsek Mts, Zsámbék Basin and Budapest, Hungary (KoreCZLAKY 1973, 1968, 1964, 1965, 1982; GöRÖG 1992; TÓTH \& GÖRÖG 2008), easternmost Pannonian and Transylvanian basins, Romania (KovÁcs 2001, SuCIU 2005, FiLIPESCU et al. 2014, Silye 2015); Romanian Plain, Romania (PoPESCU 1995), Moesian Platform, Bulgaria (Stancheva 1960); Pannonian Basin, Serbia (TER BORGH et al. 2013); Holocene: Mediterranean Sea, Italy (Melis et al. 2012, YoKeS et al. 2014). Recently widely distributed over the world.

Remarks: The number and size of spines are variable, it seems to be intraspecific variability. Making the species Elphidium josephinum described by D'ORBIGNY the junior synonym of E. aculeatum, thus an invalid name.

\section{Elphidium crispum (LiNNE, 1758) Plate I, fig. 14}

1758 Nautilus crispus n. sp. LiNNAEUs, p. 709, pl. 1, figs 2d-e. 1988 Elphidium crispum (LINNÉ) - JORISSEN, p. 120, pl. 3, figs 8-9, pl. 24, figs 1-2. 
2004 Elphidium crispum (LinNÉ) - Meriç et al., pl. 1, figs 16-18. 2004 Elphidium crispum (LINNÉ) - MENDES et al., pl. 1, fig. 6. 2004 Elphidium crispum (LINNÉ) - BRÂNZILĂ, pl. 4, fig. 11. 2005 Elphidium crispum (LinNÉ) - Morigi et al., pl. 2, fig. 9a-c. 2008 Elphidium crispum (LinNÉ) - TÓTH \& GöRÖG, pp. 205-206, pl. 3, figs 7-8. (cum syn.)

2009 Elphidium crispum (LINNÉ) - FREZZA \& CARBONI, pl. 1, fig. 16. 2010 Elphidium crispum (LinNÉ) - KouBOVA \& HudAČKOVA, pl. 1, fig. 24.

2011 Elphidium crispum (LinNÉ) - GEDL \& PERYT, fig. 9/C, R.

2012 Elphidium crispum (LinNÉ) - FERRER GARCÍA \& BLÁZQUEZ MORILLA, pl. 4, fig. 12.

2012 Elphidium crispum (LINNÉ) - GONERA, fig. 4/j.

2012 Elphidium crispum (LINNÉ) - MILKER \& SCHMIEDL, p. 120, fig. 27/13-14.

2012 Elphidium crispum (LiNNÉ) - MELIS et al., pl. 1, fig. 4. 2012 Elphidium crispum (LinNÉ) - Aloulou et al., pl. 1, fig. 15. 2014 Elphidium crispum (LinNÉ) - FILIPESCU et al., fig.7/3. 2014 Elphidium crispum (LINNÉ) - YoKEs et al., fig. 11/10-11. 2014 Elphidium crispum (LINNÉ) - TER BORGH et al., fig. 6/8. 2016 Elphidium crispum (LINNÉ) - LEI \& LI, p. 361, fig. 84. 2016 Elphidium crispum (LINNÉ) - DiMIZA et al., pl. 4, fig. 20. 2016 Elphidium crispum (LINNÉ) - PEZELJ et al., fig. 5/ D, I. 2019 Elphidium crispum (LINNÉ) - JovANOVIĆ et al., pl. 1, figs f/3, g/7. 2019 Elphidium crispum (LiNNÉ) - RosLIM et al., fig. 4/25.

Dimensions: $\mathrm{D}=450-1200 \mu \mathrm{m}, \mathrm{Th}=330-350 \mu \mathrm{m}$

Stratigraphic range and geographic distribution: Langhian: Aquitaine Basin, France (CAhUZAC \& Poignant 2000); Karpatian-Badenian: East-Mecsek Mts, Hungary (KoReCZ-LAKY 1968); Badenian: Dacian Basin, Romania and Serbia (TER Borgh et al. 2014), Carpathian Foredeep, Poland and Ukraine (GEDL \& PerYt 2011, Gonera 2012), Vienna Basin, Austria (PAPP 1963), Apennines, Italy (DIECI 1959), Koceljeva area, Western Serbia (Jovanović et al. 2019); Badenian: North-Croatian Basin, Croatia (Pezelu et al. 2016), Karpatian-Sarmatian: Transcarpathian Basin, Volhynian-Podolian Plateau and Caucasus, Ukraine and Russia (Venglinsky 1958, Didkowsky \& Satanovskaja 1970); Sarmatian: Carpathian Foredeep, Poland (SzCZECHURA 1982), Mecsek Mts, Zsámbék Basin and Budapest, Hungary (KoRECZ-LAKY 1964, 1968; GöRÖG 1992; TóTH \& GöRÖG 2008), Vienna Basin, Slovakia (KouBova \& HudAČKOVA 2010); Moldavian Plateau, Moldavia (BRÂNZILĂ 2004); Lower Sarmatian: easternmost Pannonian Basin, Romania (FILIPESCU et al. 2014); Upper Miocene: Ambug Hill, Borneo (RosLim et al. 2019); Pliocene: Toscana, Italy (FICHTEL \& MoLL 1798); Holocene: Meditterranean Sea, Italy (MoRIGI et al, 2005, Melis et al. 2012). Recently widely distributed over the world.

\section{Elphidium hauerinum (D’ORBIGNY, 1846) Plate III, fig. 6}

1846 Polystomella Hauerina n. sp. D'OrBIGNY, p.122, pl. 6, figs 5-10. 1995 Elphidium hauerinum (D’ORBIGNY) - PoPESCU, p. 95, pl. 8, fig. 10.

2005 Elphidium hauerinum (D’ORBIGNY) - FILIPESCU et al., pl. 2 , figs 4-5.

2008 Elphidium hauerinum (D’ORBIGNY) - TóTH \& GöRÖG, pl. 3, figs 10-12. (cum syn.)
2010 Elphidium hauerinum (D’ORBIGNY) - Koubová \& HudAČKOVÁ, pl. 1, fig. 18.

2011 Elphidium hauerinum (D'ORBIGNY) - FILIPESCU et al., fig. 4/3. 2011 Elphidium hauerinum (D'ORBIGNY) - IONESI \& PASCARIU, pl. 1, fig. 29.

2012 Elphidium hauerinum (D'ORBIGNY) - JASIONOWSKI et al., fig. 14/E, H, I, M.

2014 Elphidium hauerinum (D'ORBIGNY) - FILIPESCU et al., figs 7-9. 2015 Elphidium hauerinum (D'ORBIGNY) - SILYE, p. 152, pl. 8, figs 5-7.

2017 Elphidium hauerinum (D'ORBIGNY) - DUMITRIU et al., fig. 12/G, H.

Dimensions: $\mathrm{D}=240-430 \mu \mathrm{m}, \mathrm{Th}=100-150 \mu \mathrm{m}$

Stratigraphic range and geographic distribution: Badenian?: Vienna Basin, Austria (D'ORBIGNY 1846); BadenianSarmatian: Transcarpathian Basin, Carpathian Foredeep, Ukraine (VEnglinsky 1958, DidKowsky \& SatanovskaJA 1970); Sarmatian: Carpathian Foredeep, Ukraine, Poland and Romania (JASIONOWSKI et al. 2012, DuMITRIU et al. 2017), Moldavian Plateau, Romania (IONESI \& PASCARIU 2011), N-Caucasus, Russia (Voloshinova 1952); Moesian Platform, Bulgaria (STANCHEVA 1960), easternmost Pannonian and Transylvanian basins, Romania (FILIPESCU 1996; KovÁcs 2001; SucIu 2005; Filipescu et al. 2005, 2011, 2014), Romanian Plain, Romania (PoPESCU 1995), Vienna Basin, Austria (D'OrbignY 1846, PAPP 1963, SchÜTZ et al. 2007), Tokaj Mts, Zsámbék Basin, Mecsek Mts and Budapest, Hungary (KoRECZ-LAKY 1964, 1965, 1968, 1973, 1982; GöRÖG 1992; TÓTH \& GÖRÖG 2008); Danube Basin and East-Slovakian Basin, Slovakia (BRESTENSKÁ 1974, ZlinsKá 1997, KoubOvá \& HudAČKová 2010), Carpathian Foredeep, Poland (SZCZECHURA 1982, 2000).

Genus Porosononion Putrya in VoloshinOVA, 1958

Porosononion granosum (D'ORBIGNY, 1846)

Plate III, figs 5, 9 (thin section)

1846 Nonionina granosa $\mathrm{n}$. sp. D'ORBIGNY, p. 110, pl. 5, figs 19-20. 1988 Elphidium granosum (D'ORBIGNY) - JORISSEN, p. 104, pl. 2, figs $1-3$, pl. 16-19.

1992 Porosononion granosum (D’ORBIGNY) - GöRÖG, pp. 112113, pl. 11. fig. 5. (cum syn.)

2000 Porosononion granosum (D’ORBIGNY) - PoIGNANT et al., pp. 400-401, pl. 1, figs 13-14. (cum syn.)

2000 Porosononion granosum (D'ORBIGNY) - SzCZECHURA, pl. 5, figs $3,6$.

2000 Elphidium granosum (D'ORBIGNY) - CARBONI et al., fig. 10.

2001 Porosononion granosum (D'ORBIGNY) - FILIPESCU et al., pl. 3 , fig. 11.

2004 Porosononion subgranosus monogranulata GERKE BRÂNZILĂ, pl. 2, figs 7-9.

2007 Porosononion ex gr. granosum (D’ORBIGNY) - SchÜTZ et al., pl. 6, fig.6.

2007 Porosononion granosum (D'ORBIGNY) - Gross et al., pp. 210-211, fig. 4 a-e, h-i.

2008 Cribroelphidium ex gr. granosum (D’ORBIGNY) - TóTH \& GöRÖG, p. 204, pl. 3., figs 3-4.

non 2010 Porosononion granosum (D’ORBIGNY) - KoubOVÁ \& HudAČKOVÁ, pl. 1, fig. 20. 
2011 Porosononion granosum (D’ORBIGNY) - FILIPESCU et al., fig. 4/9.

2012 Elphidium granosum (D'ORBIGNY) - MiLKER \& SCHMIEDL, p. 121, fig. 27/17-18.

2013 Porosononion granosum (D'ORBIGNY) - TER BORGH et al., fig. $6 / 4-5$

2015 Porosononion granosum (D’ORBIGNY) - SILYE, p. 147, pl. 7, figs 4-5.

2018 Porosononion granosum (D'ORBIGNY) - HARZHAUSER et al., fig. 5/1-2.

2019 Porosononion granosum (D’ORBIGnY) - NÁÑez \& MALUMIÁN, pp. 197-201, figs 5-6.

Dimensions: $\mathrm{D}=200-500 \mu \mathrm{m}$

Stratigraphic range and geographic distribution: Middle Miocene: Atlantic Ocean, Argentina (NÁŃEZ \& MALUMIÁN 2019); Badenian: Transylvanian Basin, Romania (FILIPESCU 2001); Badenian-Sarmatian: Vienna Basin, Austria (D'Orbigny 1846); Sarmatian: Vienna Basin and Styrian Basin, Austria (Gross et al. 2007, ScHÜTZ et al. 2007, HARZHAUSER et al. 2018), Zsámbék Basin and Budapest, Hungary (GöRÖG 1992, TóTH \& GöRÖG 2008), Transcarpathian Basin, Ukraine (Voloshinova 1952, Venglinsky 1958), Carpathian Foredeep, Poland (Szczechura 2000), Transylvanian Basin, Romania (FilipeSCu et al. 2011, SiLYe 2015), Moldavian Plateau (BRÂNZILĂ 2004); Pliocene: Mediterranean Sea, Spain (CARbonnel \& Magné 1977) and Greece (HAGEMAN 1979). Recently widely distributed over the world.

Remarks: The umbilical region is very variable in this group. Due to the large morphological variation, the taxonomic status of fossil specimens is uncertain. The studied specimen is identical (including umbilical region) to the holotype described by D'ORBIGNY (1846).

Family Cibicididae CUSHMAN, 1927

Subfamily Cibicidinae CUSHMAN, 1927

Genus Heterolepa FranZENAU, 1884

\section{Heterolepa dutemplei (D'ORBIGNY, 1846) \\ Plate I, figs 10, 18 (thin section)}

1846 Rotalia dutemplei n. sp. D'ORBIGNY, p. 157, pl. 8, figs 19-21. 1982 Heterolepa dutemplei (D’ORBIGNY) - SZCZEChURA, pl. 16, figs 8-9.

1985 Heterolepa dutemplei (D'ORBIGNY) - PAPP \& SCHMID, p. 59, pl. 50, figs $1-3$.

1985 Heterolepa dutemplei (D'ORBIGNY) - KORECZ-LAKY \& NAGY-GeLlai, pl. 20, fig. 4a-b.

1998 Heterolepa dutemplei (D'ORBIGNY) - CiCHA et al., pp.107108 , pl. 71, figs $1-3$.

1999 Heterolepa dutemplei (D’ORBIGNY) - BÁLDI, pp. 209-210, pl.

9 , figs $1-6$, pl. 10, figs $1-2$.

2000 Heterolepa dutemplei (D’ORBIGNY) - SZCZECHURA, pl. 1, figs $6,13$.

2001 Heterolepa dutemplei (D'ORBIGNY) - FILIPESCU, pl. 3, figs 12-13. 2007 Heterolepa dutemplei (D’ORBIGNY) - OZSVÁRT, pp. 84-85, pl. 11, figs 11-13. (cum syn.)

2013 Heterolepa dutemplei (D'ORBIGNY) - PERYT, figs 4/V, W, 7/Y 2013 Heterolepa dutemplei (D'ORBIGNY) - PEZELJ et al., fig. 6/20. 2014 Heterolepa dutemplei (D'ORBIGNY) - TER BORGH et al., fig. $5 / 41-42$.
2014 Heterolepa dutemplei (D'Orbigny) - Stojanova \& Petrov, pl. 1 , fig. 11.

2016 Heterolepa dutemplei (D'ORBIGNY) - VALCHEV \& STOJANOVA, pl. 2, figs 3-4.

2016 Heterolepa dutemplei (D'ORBIGNY) - PEZELJ et al., fig. 5/M

2017 Heterolepa dutemplei (D'ORBIGNY) - HARZHAUSER et al., pl. 2, fig. 13.

2017 Heterolepa dutemplei (D'ORBIGNY) - DUMITRIU et al., fig. 9/I, J.

2019 Heterolepa dutemplei (D'ORBIGNY) - Jovanović et al., pl. 1, fig. $\mathrm{h} / 1$.

2019 Heterolepa dutemplei (D’ORBIGNY) - RosLIM et al., fig. 4/8-13.

Dimensions: $\mathrm{D}=450-600 \mu \mathrm{m}, \mathrm{Th}=200-350 \mu \mathrm{m}$

Stratigraphic range and geographic distribution: Middle to Upper Eocene: Paleogene Basin, Hungary (OzSvÁrT 2007); Upper Eocene - Lower Oligocene: ValandovoGevgelia Basin, Republic of Macedonia (Stojanova \& Petrov 2014; Valchev \& Stojanova 2016); Kiscellian to Badenian: Börzsöny Mts, Hungary (KoRECZ-LAKY \& NAGY-GellaI 1985); SW-Hungary (BÁLDI 1999); Ottnangian: Austria, Vienna Basin (HARZHAUSER et al. 2017); Badenian: Koceljeva area, Western Serbia (Jovanović et al. 2019); Mt Majevica, Bosnia and Herzegovina (PezelJ et al. 2013); North-Croatian Basin, Croatia (Pezelu et al. 2016), Austria, Vienna Basin (D’ORbigny 1846), Dacian and Transylvanian basins, Serbia and Romania (FILIPESCU 2001, TER BORGH et al. 2014); Carpathian Foredeep, Poland (SzCZeChuRA 1982, 2000; PerYt 2013; Dumitriu et al. 2017), Upper Miocene: Ambug Hill, Borneo (RosLim et al. 2019).

\section{Ostracoda}

Classification of the ostracods follows that of HARTMANN \& PURI (1974) and HoRne et al. (2002). Abbreviations: L: length, $\mathrm{H}$ : height.

Phylum Arthropoda SiEbold, Stannius, 1845

Subphylum Crustacea PENNANT, 1777

Class Ostracoda LATREILLE, 1802

Order Podocopida MüLLER, 1894

Suborder Cytherocopina BAIRD, 1850

Superfamily Cytheroidea BAIRD, 1850

Family Cytherideidae SARS, 1925

Subfamily Cytherideinae SARS, 1925

Genus Cyprideis Jones, 1857

Cyprideis pokorny JIŘıČEK, 1974

Plate II, figs 8-9

1974 Cyprideis pokorny n. sp. JIŘIČEK, p. 439, pl. 2, figs 1-4. 2009 Cyprideis pokorny JIŘIČEK - TóTH, p. 87, pl. 4, figs 3,6.

Dimensions: $\mathrm{L}=660-720 \mu \mathrm{m}, \mathrm{H}=350-410 \mu \mathrm{m}, \mathrm{L} / \mathrm{H}=1.6-1.8$. Stratigraphic range and geographic distribution: Upper Sarmatian: Vienna Basin, Slovakia (JIŘIČEK 1974); Vértes Hill, Hungary (Тóтн 2009). 
Family Hemicytheridae PURI, 1953

Subfamily Hemicytherinae PURI, 1953

Genus Aurila POKORNÝ, 1955

Aurila cicatricosa (REUSS, 1850)

Plate I, figs 2-3

1850 Cypridina cicatricosa n. sp. Reuss, pp. 67-68, pl. 9, fig. 21. 1962 Mutilus (Aurila) cicatricosa (Reuss) - STANCHEVA, p. 32, pl. 4 , fig. 8.

1971 Aurila cicatricosa (REUSS) - CERNAJSEK, pp. 65-69, pl. 6, figs 7-14, pl. 14, fig. 7, pl. 17, fig. 4 a-b. [partim, pl. 14, fig. 8]

1978 Aurila cicatricosa (REUSS) - BRESTENSKÁ \& JIŘIČEK, p. 409, 432, pl. 6, fig. 1.

2008 Aurila cicatricosa (ReUss) - FARANDA et al., pl. 2, figs 4-5.

2004 Aurila cicatricosa (REUSS) - AIELlo \& SZCZECHURA, pp. 28 30 , pl. 5 , fig. 2.

2006 Aurila cicatricosa (Reuss) - GRoss \& PILlER, pp. 47-48, text-fig. 6/1, pl. 21, figs 1-12, pl. 22, figs 8-10.

2006 Aurila cicatricosa (REUSs) - SzCZECHURA, fig. 9/9-10.

2012 Aurila cicatricosa (REUSs) - SEKO et al., fig.8/P.

2014 Aurila (Aurila) cicatricosa (REUSS) - TER BORGH et al., fig. $7 / 16$.

Dimensions: $\mathrm{L}=900-950 \mu \mathrm{m}, \mathrm{H}=530-580 \mu \mathrm{m}, \mathrm{L} / \mathrm{H}=$ 1.6-1.7.

Stratigraphic range and geographic distribution: Badenian: Vienna Basin, Austria (CERNAJSEK 1971, Gross \& PILLER 2006); Carpathian Foredeep, Czech Republic, Poland (BRESTENSKÁ \& JiŘIČEK 1978, AIELlo \& SZCZECHURA 2004, SzCZECHURA 2006, SEKo et al. 2012); Dacian Basin, Romania (TER BorGH et al. 2014); Late Miocene: Mediterranean, Greece (FARANDA et al. 2008).

\section{Aurila notata (REUSS, 1850)}

Plate II, figs 12-13.

1850 Cypridina notata $\mathrm{n}$. sp. Reuss, p. 66, pl. 9, fig. 16.

2006 Aurila (Euaurila?) notata (REUSS) - GROSS \& PILLER, p. 8384, pl. 29, figs 1-9.

2008 Aurila notata (Reuss) - TóтH, pp. 122-123, pl.8. figs 3-7. (cum syn.)

2017 Aurila notata (Reuss) - DUMITRIU et al., fig. 12/Q.

2018 Aurila notata (Reuss) - HARZHAUSER et al., fig. 7/10.

Dimensions: $\mathrm{L}=900-950 \mu \mathrm{m}, \mathrm{H}=530-580 \mu \mathrm{m}, \mathrm{L} / \mathrm{H}=$ 1.6-1.7.

Stratigraphic range and geographic distribution: Upper Sarmatian: Vienna Basin, Austria and Slovakia (CERNAJSEK 1974, JiŘIČEK 1983, ZELENKA 1990, JANZ \& VENNEMANN 2005, Gross \& Piller 2006, Harzhauser et al. 2018); Zsámbék Basin, Hungary (TóTH 2008); Caucasus, Russia (SuZIN 1956); Lower Sarmatian: Moldovian Plateau. Romania (Dumitriu et al. 2017).

Genus Hemicytheria POKORNÝ, 1952

Hemicytheria omphalodes (REUSS, 1850) Plate II, fig. 11

1850 Cypridina omphalodes n. sp. Reuss, p. 75, pl. 10, fig. 7.

2008 Hemicytheria omphalodes (REuss) - TóTH, pl. 6, figs 2-6. (cum syn.)
2011 Hemicytheria omphalodes (Reuss) - OlteAnU, pl. 18, fig. 8 2014 Hemicytheria omphalodes (REUSS) - FILIPESCU et al., fig. $8 / 10$.

Dimensions: $\mathrm{L}=810-820 \mu \mathrm{m}, \mathrm{H}=470-480 \mu \mathrm{m}, \mathrm{L} / \mathrm{H}=$ $1.7-1.75$.

Stratigraphic range and geographic distribution: Upper Badenian: Transylvanian Basin, Romania (OLTEANU 2001); Sarmatian: Vienna Basin, Slovakia (JiŘıčEK 1974, ZELENKA 1990); Zsámbék Basin, Hungary (TóTH 2008); Lower Sarmatian: Danube Basin and the eastern region, Slovakia (Fordinál et al. 2006, FordinÁl \& ZlinsKá 1994); Upper Sarmatian: Vienna Basin, Austria (CERNAJSEK 1974); Pannonian: easternmost Pannonian Basin, Transylvanian Basin, Romania (OlteAnu 2001, 2011; FiliPesCU et al. 2014), Pannonian Basin, Croatia (SoKAČ 1972).

Genus Senesia JIŘIČEK, 1974

\section{Senesia cinctella (REUSS, 1850)}

Plate I, fig. 6

1850 Cypridina cinctella n. sp. Reuss, p. 67, pl. 9, fig. 19.

1962 Mutilus (Aurila) cinctella (REUSS) - STANCHEVA, p. 35, pl. 4, fig. 9.

1979 Aurila (Aurila) cinctella n. ssp. - BASSIOUNI, pp. 118-119, pl. 19, figs 7-8.

2006 Senesia cinctella (REUss) - GROSs \& PILler, pp. 57-58, pl. 31, figs $1-5$.

Dimensions: $\mathrm{L}=750-760 \mu \mathrm{m}, \mathrm{H}=410-420 \mu \mathrm{m}, \mathrm{L} / \mathrm{H}=$ $1.8-1.82$

Stratigraphic range and geographic distribution: Lower Miocene: Black Sea Depression, Turkey (BASsIOUNI 1979); Badenian: Vienna Basin, Austria and Slovakia (REUss 1850, Cernajsek 1971, Brestenská \& JiŘIČEK 1978, Gross \& PILler 2006); Moesian Plateau, Bulgaria (StANCHEVA 1962).

Subfamily Urocythereidinae HARTMANN \& PURI, 1974

Genus Urocythereis RUGGIERI, 1950

Urocythereis kostelensis (REUSS, 1850) Plate I, fig. 4

1850 Cypridina kostelenis n. sp. Reuss, p. 68, pl. 9, fig. 22.

1978 Urocythereis kostelensis (REUSS) - BRESTENSKÁ \& JIŘIČEK, p. 410, 432, pl. 6, fig. 12.

1985 Urocythereis kostelenis (REUSs) -ZELENKA, p. 246, pl. 3, fig. 2. 2004 Urocythereis kostelenis (REUSs) - ZoRN, p. 180, fig. 4/10-11. 2006 Urocythereis kostelenis (REUSS) - Gross \& PILlER, pp. 106108 , pl. 38, figs $1-5,9,11-12$.

Dimensions: $\mathrm{L}=820-835 \mu \mathrm{m}, \mathrm{H}=410-420 \mu \mathrm{m}, \mathrm{L} / \mathrm{H}=$ 1.9-2.

Stratigraphic range and geographic distribution: Badenian: Carpathian Foredeep, Poland (Reuss 1850), Vienna and Molasse basins, Austria and Slovakia (REuss 1850, BRESTENSKÁ \& JiŘIČEK 1978, ZELENKA 1985, ZORN 2004; Gross \& Piller 2006). 
Family Leptocytheridae HANAI, 1957

Subfamily Leptocytherinae HANAI, 1957

Genus Amnicythere Devoto, 1965

\section{Amnicythere cernajseki STANCHEVA, 1984}

Plate II, figs 2-3

1963 Leptocythere modesta n. sp. StAncheVA, p. 22, pl. 3, fig. 8. 1974 Leptocythere sp. - CERNAJSEK, p. 476, pl. 2, fig. 7.

1984 Amnicythere cernajseki nom. nov. - STANCHEVA, p. 39, pl. 1, fig. 5 .

1998 Amnicyther aff. plana (SCHNEIDER) - OltEANU, p. 153, pl. 8,

fig. 7.

2008 Amnicythere (?) sp.- TóTH, p. 110, pl. 2, figs 5-6.

2011 Amnicythere cernajseki STANCHEVA - FILIPESCU et al., fig. $5 / 20$.

Dimensions: $\mathrm{L}=570-600 \mu \mathrm{m}, \mathrm{H}=260-300 \mu \mathrm{m}, \mathrm{L} / \mathrm{H}=2-$ 2.19 .

Stratigraphic range and geographic distribution: Sarmatian: Vienna Basin, Austria (CERNAJSEK 1974); Lower Sarmatian: Transylvanian Basin, Romania (OltEANU 1998); Upper Sarmatian: Zsámbék Basin, Hungary (TóTH 2008); Transylvanian Basin, Romania (FILIPESCU et al. 2011).

\section{Amnicythere tenuis (REUSs, 1850) \\ Plate II, fig. 1}

1850 Cytherina tenuis n. sp. Reuss, p. 53, pl. 8, fig. 14.

2008 Amnicythere tenuis (REUSs) - TóTH, p. 109-110, pl. 2, figs 13, 5. (cum syn.)

2013 Amnicythere tenuis (REUSS) - TER BORGH et al., fig. 6/14-15. 2014 Amnicythere tenuis (REUSS) - TER BORGH et al., fig. 8/27-28. 2015 Amnicythere tenuis (REUSs) - SILYE, pl. 10, figs 1-3.

2018 Amnicythere tenuis (REUSs) - HARZHAUSER et al., fig. 7/3.

Dimensions: $\mathrm{L}=510-550 \mu \mathrm{m}, \mathrm{H}=250-290 \mu \mathrm{m}, \mathrm{L} / \mathrm{H}=$ 1.96-2.3.

Stratigraphic range and geographic distribution: Sarmatian: Vienna Basin, Austria (CERNAJSEK 1974, HARZHAUSER et al. 2018); Carpathian Foredeep, Poland (SzCZECHURA 2000); Zsámbék Basin and Budapest, Hungary (TóTH 2004, 2008); Lower Sarmatian: East-Slovakian Basin, Slovakia (ZlinsKÁ \& FORDINÁL 1995); Transylvanian Basin, Romania (Olteanu 1998, Silye 2015); Pannonian and Dacian basins, Serbia and Romania (TER BORGH et al. 2013, 2014); Bessarabian: Moesian Plate, Bulgaria (STANCHEvA 1963, 1990); Pannonian: Pannonian Basin, Hungary (MéHes 1908); Pontian: Dacian Basin, Romania (HANGANu 1974).

Genus Callistocythere RUGGIERI, 1953

\section{Callistocythere canaliculata (REUSS, 1850)} Plate I, fig. 1

1850 Cypridina canaliculata $\mathrm{n}$. sp. Reuss, p. 76, pl. 9, fig. 12. 2006 Callistocythere canaliculata (Reuss) - Gross \& PILLER, pp. 25-26, pl. 8, figs $1-4,8-9$, pl. 10, figs 1-2. (cum syn.) 2011 Callistocythere aff. canaliculata (REUSS) - HAJEK-TADESSE \& PRTOLJAN, figs 4, 9.

2019 Callistocythere canaliculata (REUss) - BRINKMANN et al., fig. 4/P.
Dimensions: $\mathrm{L}=570-600 \mu \mathrm{m}, \mathrm{H}=260-300 \mu \mathrm{m}, \mathrm{L} / \mathrm{H}=2-$ 2.19 .

Stratigraphic range and geographic distribution: Ottnangian: North Alpine Foreland Basin, Germany (BRINKMANN et al. 2019); Karpatian: Molasse Basin, Austria (ZORN 2003, 2004); Badenian: Vienna Basin and Danube Basin, Slovakia (BRESTENSKÁ \& JiŘIČEK 1978, GROSS \& PILlER 2006); Transylvanian Basin, Romania (OlteAnU 1998); Carpathian Foredeep, Poland (PARUCH-KulCZYCKA 1992; PARUCH-KulczYCKA \& SzCZEChura 1996, Aiello \& SzCZECHURA 2004); Sarmatian: Tokaj Mts, Hungary (PIETRZENIUK 1973); North-Croatian Basin, Croatia (HAJEK-TADESSE \& PRTOLJAN 2011).

Genus Euxinocythere STANCHEVA, 1968

Euxinocythere (Euxinocythere) naca (MÉHES, 1908) Plate II, fig. 7

1908 Cythere naca n. sp. MÉHEs, p. 548-549, pl. 10, figs 8-12. 1989 Leptocythere naca (MÉHES) - SOKAČ, p. 687, pl. 8, fig 10. 1989 Leptocythere (Amnicythere) naca (MÉHES) - OltEAnU, pl. 8, fig. 6 .

1989 Euxinocythere (Euxinocythere) cf. naca (MÉHES) - KRSTIĆ \& StancheVA, p. 778, pl. 11, fig. 3.

2008 Euxinocythere (Euxinocythere) naca (MÉHES) - TóTH, pp. 112-113, pl. 1, fig.7. (cum syn.)

2009 Euxinocythere (Euxinocythere) naca (MÉHES) - TóTH, p. 84, pl. 3 , fig. 3 .

2011 Leptocythere (Euxinocythere) naca (MÉHES) - OltEAnU, pl. 19, fig. 1.

2013 Euxinocythere naca (MÉHES) - TER BORGH et al., fig. 8/10.

Dimensions: $\mathrm{L}=470-510 \mu \mathrm{m}, \mathrm{H}=235-260 \mu \mathrm{m}, \mathrm{L} / \mathrm{H}=$ 1.88-1.95.

Stratigraphic range and geographic distribution: Sarmatian: Vienna and Danube basins, Austria and Slovakia (Cernajsek 1974, Zelenka 1990); Moldavian Plateau, Romania (IONESI \& CHINTĂUAN 1975, 1985); Carpathian Foredeep, Poland (Szczechura 2000); Volhynian: Moesian Plate, Northern Bulgaria (STANCHEVA 1990); Zsámbék Basin, Hungary (Tóth 2008, 2009); Pannonian-Pontian: Pannonian Basin, Hungary and Serbia (Krstić 1973, MÉHES 1908, SzÉles 1982, Krstić \& Stancheva 1989; TER BorGH et al. 2013); North-Croatian Basin, Croatia (SoKAČ 1967, 1972, 1989); Transylvanian Basin, Romania (OlteAnu 2011); Pontian: Dacian Basin, Romania (OlteAnu 1989); South Caspian Basin, Azerbaijan (Agalarova 1967).

Euxinocythere (Euxinocythere) praebosqueti (SUZIN, 1956) Plate II, figs 4-6

1956 Leptocythere praebosqueti n. sp. SuzIN, p. 83, pl. 3, figs 2-4. 2008 Euxinocythere (Euxinocythere) praebosqueti (SuZIN) Tóth, p. 114, pl. 3, figs 2-5. (cum syn.)

2013 Euxinocythere (Euxinocythere) praebosqueti (SUZIN) - VAN BAAK et al., fig. 4/13.

Dimensions: $\mathrm{L}=490-510 \mu \mathrm{m}, \mathrm{H}=200-260 \mu \mathrm{m}, \mathrm{L} / \mathrm{H}=$ 1.9-2.1. 
Stratigraphic range and geographic distribution: Sarmatian: Moesian Plate, Northern Bulgaria (Stancheva 1972, 1990); Upper Sarmatian: Zsámbék Basin, Hungary (TóTH 2008); Bessarabian: Caucasus, Russia (SuZIN 1956); Plio-Pleistocene: South Caspian Basin, Azerbaijan (vaN BAAK et al. 2013).

Family Loxoconchidae SARS, 1925

Subfamily Loxoconchinae SARS, 1925

Genus Loxoconcha SARS, 1866

\section{Loxoconcha kochi MÉHES, 1908 Plate II, figs $14-15$}

1908 Loxoconcha kochi $\mathrm{n}$. sp. MÉHES, pp. 543-544, pl. 9, figs 5-9. 2005 Loxoconcha kochi MéHES - FILIPESCU et al., pl. 3, fig. 6.

2006 Loxoconcha kochi? MÉHES - GROSS \& PILLER, pp. 112-113, pl. 40, figs 1-7,9.

2008 Loxoconcha kochi MÉHES - TóTH, p. 124, pl. 9, fig. 6. (cum syn.)

2013 Loxoconcha kochi MéHES - TER BORGH et al., fig. 8/24-25. 2014 Loxoconcha kochi MÉHES - TER BORGH et al., fig. 7/23. 2014 Loxoconcha kochi MÉHES - FILIPESCU et al., fig.8/15. 2018 Loxoconcha kochi MÉHES - HARZHAUSER et al., fig. 7/12.

Dimensions: $\mathrm{L}=640-835 \mu \mathrm{m}, \mathrm{H}=400-520 \mu \mathrm{m}, \mathrm{L} / \mathrm{H}=$ 1.6-1.75.

Stratigraphic range and geographic distribution: Upper Badenian: Vienna Basin, Austria (Gross \& PILler 2006); Dacian Basin, Romania (TER BorGH et al. 2014); Sarmatian: Vienna Basin, Austria (CERnAJseK 1974, Gross \& Piller 2006, HARZHAUSER et al. 2018); easternmost Pannonian and Transylvanian basins, Blacks Sea Depression, Romania (IONESI \& ChintăUAN 1985; FILIPESCU et al. 2005, 2014); Upper Sarmatian: Zsámbék Basin, Hungary (TóTH 2008); Pannonian Basin, Serbia (TER BoRGH et al. 2013); Lower Pannonian (?): Pannonian Basin, Hungary (MéHes 1908); Messinian and Pliocene (?): Rhône Valley, France (CARBONNEL 1978).

\section{Loxoconcha laeta STANCHEVA, 1963 Plate II, fig. 16}

1963 Loxoconcha laeta n.sp. STANCHEVA, pp. 34-35, pl.6, fig 9. 1990 Loxoconcha laeta STANCHEVA - STANCHEVA, pp. 88-89, pl. 31, figs 5-6.

2009 Loxoconcha laeta STANCHEVA - Tóth, pp. 91-92, pl. 7, fig. 12.

Dimensions: $\mathrm{L}=720-750 \mu \mathrm{m}, \mathrm{H}=390-410 \mu \mathrm{m}, \mathrm{L} / \mathrm{H}=$ 1.8-1.83.

Stratigraphic range and geographic distribution: Lower Sarmatian: Moesian Plate, Bulgaria (STANCHEva 1963, 1990); Upper Sarmatian: Zsámbék Basin, Hungary (Тótн 2009).

\section{Loxoconcha porosa MÉHES, 1908}

Plate II, fig. 17

1908 Loxoconcha porosa n. sp. MÉHES, pp. 542-543, pl. 8, figs 10-14. 2008 Loxoconcha porosa MÉHES - TóTH, pp. 124-125, pl. 9, figs 3-5. (cum syn.)
Dimensions: $\mathrm{L}=620-700 \mu \mathrm{m}, \mathrm{H}=420-470 \mu \mathrm{m}, \mathrm{L} / \mathrm{H}=$ 1.45-1.55.

Stratigraphic range and geographic distribution: Sarmatian: Pannonian Basin, Serbia (KRSTIĆ 1972); Black Sea Depression, Romania (IONESI \& CHINTĂUAN 1985); Upper Sarmatian: Vienna Basin, Slovakia (Zelenka 1990); Zsámbék Basin, Hungary (То́тн 2008); Pannonian: Pannonian Basin, Hungary and Croatia (MÉHES 1908, SOKAČ 1972).

\section{Loxoconcha punctatella (REUSs, 1850)} Plate I, fig. 5

1850 Cypridina punctatella $\mathrm{n}$. sp. ReUss, pp. 65-66, pl. 9, fig. 15 a-b. 1978 Loxoconcha punctatella (REUSS) - BRESTENSKÁ \& JIŘIČEK, pl. 2, figs 12-13.

1985 Loxoconcha punctatella (REUSS) - ZELENKA, pl. 3, figs 10-11. 2004 Loxoconcha ex. gr. punctatella (REUSs) - TóTH, pp. 140-141, pl. 6, figs 1-2.

2006 Loxoconcha punctatella (REUSs) - GROSS \& PILLER, pp. $73-$ 74 , pl. 40, figs 8,11, pl. 41, figs 1-10. (cum syn.)

2006 Loxocorniculum cf. punctatella (REUSS) - SZCZECHURA, fig. $10 / 3$.

2008 Loxoconcha ex. gr. punctatella (REUss) - TótH, p. 125, pl. 10, figs $1-2$.

2011 Loxoconcha punctatella (REUSS) - HAJEK-TADESSE \& PRTOLJAN, fig. $4 / 16$.

2012 Loxoconcha punctatella (REUSS) - SEKO et al., fig. 8/D.

2013 Loxoconcha punctatella (REUSS) - TER BORGH et al., fig. 6/28.

2019 Loxoconcha punctatella (REUSS) - BRINKMANN et al., fig. 8/N-O.

Dimensions: $\mathrm{L}=540-670 \mu \mathrm{m}, \mathrm{H}=400-450 \mu \mathrm{m}, \mathrm{L} / \mathrm{H}=$ 1.4-1.54.

Stratigraphic range and geographic distribution: Burdigalian: Molasse Basin, Austria (BRINKMANn et al. 2019); Karpatian: Molasse Basin, Austria (ZoRn 1998); Badenian: Danube Basin and Vienna Basin, Slovakia (BRESTENSKÁ \& JIŘIČEK 1978, ZelenkA 1985); Molasse Basin, Austria (ZoRn 2004); Carpathian Foredeep, Czech Republic and Poland (Paruch-KulczycKa 1992, Szczechura 2006, SeKO et al. 2012); North-Croatian Basin, Croatia (HAJEK-TADESSE \& PRTOLJAN 2011); Badenian to Sarmatian: Vienna Basin, Austria (Gross \& PILler 2006); Lower Sarmatian: Zsámbék Basin, Hungary (TóTH 2004, 2008); Pannonian Basin, Serbia (TER BORGH et al. 2013).

Genus Loxocorniculum Benson \& COLEMAN, 1963

Loxocorniculum hastatum (REUss, 1850) Plate II, figs 19-20

1850 Cytherina hastata REUSS sensu CERNAJSEK - REUSS, pl. 9, fig. 26. 2008 Loxocorniculum hastatum (REUSs) - TóTH, pp.125-126, pl. 9, figs $1-2$. (cum syn.)

2012 Loxocorniculum hastatum (REUss) - SEKO et al., fig. 8/F.

2014 Loxocorniculum hastatum (REUSS) - TER BORGH et al., fig. $7 / 22$.

2017 Loxocorniculum hastatum (REUSs) - DUMITRIU et al., fig. 13/I-J.

2019 Loxocorniculum hastatum (REUSs) - BRINKMANN et al., p. 84, fig. $8 / \mathrm{M}$. 
Dimensions: $\mathrm{L}=620-630 \mu \mathrm{m}, \mathrm{H}=390-410 \mu \mathrm{m}, \mathrm{L} / \mathrm{H}=$ 1.5-1.6.

Stratigraphic range and geographic distribution: Oligocene to Miocene (Aquitanian, Burdigalian, Langhian): Aquitaine Basin, France (DuCASSE et al. 1991, BEKAERT et al. 1991, DuCASSE \& CAHUZAC 1996); Burdigalian: Molasse Basin, Austria (BrinkMAnN et al. 2019); Rhône Basin, France (CARBOnNEl 1969); Eggenburgian: Molasse Basin, Austria (Kollmann 1971); Karpatian: Vienna Basin, Czech Republic (KHEIL 1967); Molasse Basin, Austria (ZoRn 1998, 2003, 2004); Badenian: Molasse Basin, Austria (Zorn 1998, 2004); Carpathian Foredeep, Poland and Czech Republic (PARuch-Kulczycka 1992, SzCZeChura 2006, Seko et al. 2012); Vienna Basin, Austria and Czech Republic (CERnAJSEK 1974, BRESTENSKÁ \& JIǨIČEK 1978, JANZ \& VENNEMANN 2005, Zelenka 1985); Moesian Platform, Bulgaria (StanCHEVA 1962); Dacian Basin, Romania (TER BORGH et al. 2014); Carpathian Foredeep, Poland (AIELlo \& SzCZECHURA 2004); Sarmatian: Mecsek Mts and Zsámbék Basin, Hungary (SZUROMI-KoRECZ \& SZEGŐ 2001, TóTH 2008); Carpathian Foredeep, Poland (Dumitriu et al. 2017).

Family Xestoleberididae SARS, 1928

Genus Xestoleberis SARS, 1866

\section{Xestoleberis dispar Mueller, 1894 Plate I, fig. 8}

1894 Xestoleberis disparn. sp. MÜLLER, p. 334, pl. 25, figs 2, 3, 9, 35. 1982 Xestoleberis dispar MüLLER - FARANDA et al., pl. 2, figs 16-17. 1986 Xestoleberis sp. - Mostafawi, pl. 3, fig. 33.

2006 Xestoleberis aff. dispar MÜLLER - GROSs \& PILLER, pp. 137138, pl. 2, fig. 4.

2008 Xestoleberis dispar MÜLLER - KoEHn-ZANINETTI \& TÉTARD, fig. $4 / 10$.

2014 Xestoleberis dispar (MUELLER) - TER BORGH et al., fig.7/26-27. 2015 Xestoleberis dispar MUELLER - SCIUTO et al., pl. 2, fig. 6. 2016 Xestoleberis dispar MUELLER - PARLAK \& NAZIK, pl. 3, fig. 14. 2017 Xestoleberis fuscata SCHNEIDER - DUMITRIU et al., fig. 13/H.

Dimensions: $\mathrm{L}=660-665 \mu \mathrm{m}, \mathrm{H}=350-370 \mu \mathrm{m}, \mathrm{L} / \mathrm{H}=$ 1.80-1.88.

Stratigraphic range and geographic distribution: Badenian: Dacian Basin, Romania (TER BORGH et al. 2014); upper Badenian to lower Sarmatian: Vienna Basin, Austria (Gross \& PILler 2006); lower Sarmatian: Carpathian Foredeep, Poland (Dumitriu et al. 2017); Tortonian, Pleistocene: Mediterranean Sea, Greece (FARANDA et al. 2008, MostafaWI 1986); Recently widely distributed in the Mediterranean Sea.

Xestoleberis tumida (Reuss, 1850)

Plate I, fig. 7

1850 Cytherina tumida n. sp. Reuss, pp. 57-58, pl.8, fig. 29.

2006 Xestoleberis tumida (Reuss) - Gross \& PilleR, pp. 134-137.

pl. 48, figs $1-10$, pl. 49, figs $1-5$, pl. 51, fig. 7. (cum syn.) 2006 Xestoleberis cf. tumida (REUSS) - SZCZECHURA, fig. 10/2,4.

Dimensions: $\mathrm{L}=510-540 \mu \mathrm{m}, \mathrm{H}=320-330 \mu \mathrm{m}, \mathrm{L} / \mathrm{H}=$ $1.6-1.8$.
Stratigraphic range and geographic distribution: Karpatian: Molasse Basin, Austria (ZORN 1998); Badenian: Carpathian Foredeep, Poland (SzCZEchura 2006); Austria (ZORN 1998; GROSS \& PILleR 2006).

Suborder Cypridocopina BAIRD, 1845

Superfamily Cypridoidea BAIRD, 1845

Family Cyprididae BAIRD, 1845

Subfamily Cyprinotinae BRonshteIn, 1947

Genus Heterocypris Claus, 1892

Heterocypris salina (BRADY, 1868)

Plate II, fig. 26

1868 Cypris salina n. sp. BRADY, p. 368; pl. 28, figs 8-13.

1980 Heterocypris salina salina (BRADY) - FREELS, p. 28. pl. 3, figs

1-6. cum syn.

2000 Heterocypris salina (BRADY) - MEISCH, pp. 349-352, fig. 135.

2003 Heterocypris salina (BRADY) - MischKE et al., fig. 1/7.

2004 Heterocypris salina (BRADY) - PIPÍK, p.227, pl. 1, figs 6-7.

2005 Heterocypris salina (BRADY) - MATZKE-KARASZ, p. 126, pl.

3 , fig. 4.

2005 Heterocypris salina (BRADY) - SCHARF et al., pl. 2, figs 1720.

2008 Heterocypris salina (BRADY) - NAZIK et al., pl. 1, fig. 15.

2008 Heterocypris salina (BRADY) - POQUET et al., fig. 6/I.

2012 Heterocypris salina (BRADY) - MiSCHKE et al., pl. 1, figs 7$10,18$.

2014 Heterocypris salina (BRADY) - SCHARF \& MEISCH, fig. 3/I-K. 2014 Heterocypris salina (BRADY) - MisCHKE et al., fig. 7/2.

2016 Heterocypris salina (BRADY) - SALEL et al., pl. 4, figs 4-6.

2019 Heterocypris salina (BRADY) - TUNCER et al., pl. 1, figs 1-3.

Dimensions: $\mathrm{L}=945-955 \mu \mathrm{m}, \mathrm{H}=565-590 \mu \mathrm{m}, \mathrm{L} / \mathrm{H}=$ 1.61-1.67.

Stratigraphic range and geographic distribution: Widely distributed in upper Miocene to Holocene freshwater to saline habitats (riverine pools and lakes) in Europe (MEISCH 2000) and recently over the world.

Suborder Darwinulocopina BRADY \& NORMAN, 1889

Superfamily Darwinuloidea BRADY \& NORMAN, 1889

Family Darwinulidae BRADY \& NORMAN, 1889

Genus Darwinula BRADY \& NORMAN, 1889

Darwinula stevensoni (BRADY \& ROBERTSON, 1870) Plate II, fig. 21

1870 Polycheles stevensoni m. BRADY \& ROBERTSON, pp. 25-26, pl. 7, figs 1-7, pl. 10, figs 4-14.

2000 Darwinula stevensoni (BRADY \& ROBERTSON) - MEISCH, p. 49, fig. 16/A-E.

2004 Darwinula stevensoni (BRADY \& ROBERTSON) - PIPÍK et al., pl. 1, fig. 10.

2005 Darwinula stevensoni (BRADY \& ROBERTSON) - CABRAL et al., pp. 53-55, pl. 1, figs 1-6. (cum syn.)

2012 Darwinula stevensoni (BRADY \& ROBERTSON) - FUHRMANN, pl. 1, figs $1 \mathrm{a}-\mathrm{f}$.

Dimensions: $\mathrm{L}=670-680 \mu \mathrm{m}, \mathrm{H}=420-425 \mu \mathrm{m}, \mathrm{L} / \mathrm{H}=$ 1.59-1.6.

Stratigraphic range and geographic distribution: Wide- 
ly distributed in Oligocene to Holocene lacustrine environments in Europe (MEISCH 2000) and recently over the world.

Genus Vestalenula Rossetti \& MARTEns, 1998

Vestalenula pagliolii (Pinto \& KotZian, 1961) Plate II, figs 22-23; Plate III, fig. 10 (thin-section)

1961 Darwinula pagliolii n. sp. PinTo \& Kotzian, p. 27, pl. 1, figs $1-5$, pl. 3, figs 1-4, pl. 5, figs 1-9, pl. 6, figs 1-9, pl. 9, figs $1-9$. 2003 Vestalenula pagliolii (PINTO \& KotZIAN) - PIPÍK \& BODERGAT, p. 348, pl. 1, figs 5-10, fig. 24. (cum syn.)
2004 Vestalenula pagliolii (PINTO \& KotZIAN) - PiPÍK et al., pl. 1, fig. 11.

2005 Vestalenula pagliolii (PINTO \& KotZIAN) - CABRAL et al., pp. 59-60, pl. 3, figs 5-16.

Dimensions: $\mathrm{L}=455-470 \mu \mathrm{m}, \mathrm{H}=210-220 \mu \mathrm{m}, \mathrm{L} / \mathrm{H}=$ 2.16-2.18.

Stratigraphic range and geographic distribution: Widely distributed in Oligocene to Holocene freshwater to oligohaline habitats (riverine pools and lakes) in Europe (MEISCH 2000) and recently in Brazil (MARTENS et al. 1997). 